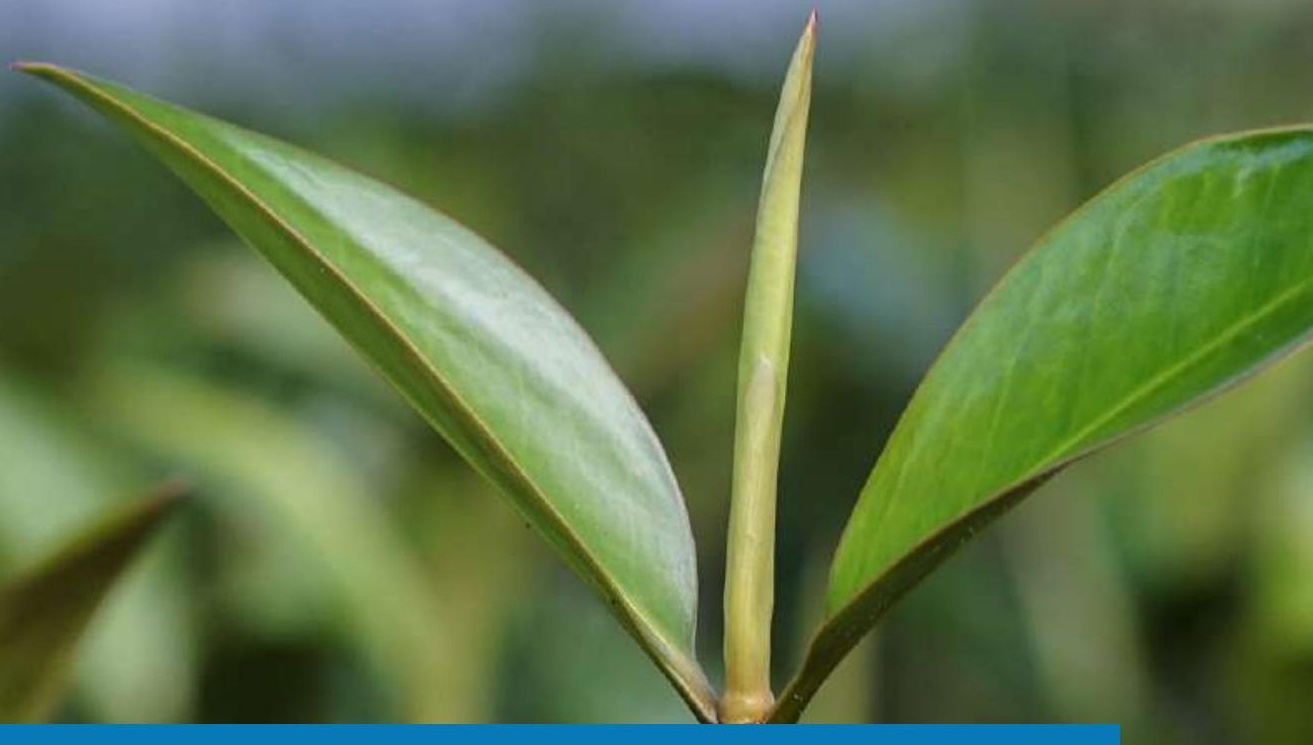

COMMUNITY-BASED MANGROVE PLANTING HANDBOOK FOR PAPUA NEW GUINEA

\title{
DECEMBER 2018
}
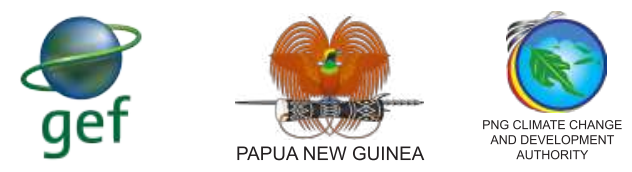

$\mathrm{ADB}$ 



\section{COMMUNITY-BASED MANGROVE PLANTING HANDBOOK FOR PAPUA NEW GUINEA}

DECEMBER 2018
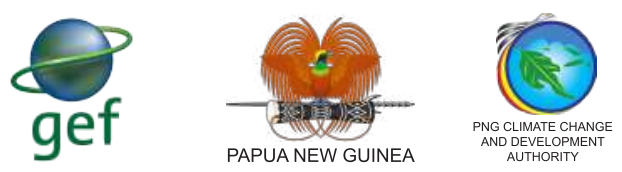
(C) 2018 Asian Development Bank

6 ADB Avenue, Mandaluyong City, 1550 Metro Manila, Philippines

Tel +632632 4444; Fax +6326362444

www.adb.org

Some rights reserved. Published in 2018.

ISBN 978-92-9261-474-4 (print), 978-92-9261-475-1 (electronic)

Publication Stock No. TIM189796-2

DOI: http://dx.doi.org/10.22617/TIM189796-2

The views expressed in this publication are those of the authors and do not necessarily reflect the views and policies of the Asian Development Bank (ADB) or its Board of Governors or the governments they represent.

ADB does not guarantee the accuracy of the data included in this publication and accepts no responsibility for any consequence of their use. The mention of specific companies or products of manufacturers does not imply that they are endorsed or recommended by ADB in preference to others of a similar nature that are not mentioned.

By making any designation of or reference to a particular territory or geographic area, or by using the term "country" in this document, ADB does not intend to make any judgments as to the legal or other status of any territory or area.

This work is available under the Creative Commons Attribution 3.0 IGO license (CC BY 3.0 IGO) https://creativecommons.org/licenses/by/3.o/igo/. By using the content of this publication, you agree to be bound by the terms of this license. For attribution, translations, adaptations, and permissions, please read the provisions and terms of use at https://www.adb.org/terms-use \#openaccess.

This CC license does not apply to non-ADB copyright materials in this publication. If the material is attributed to another source, please contact the copyright owner or publisher of that source for permission to reproduce it. ADB cannot be held liable for any claims that arise as a result of your use of the material.

Please contact pubsmarketing@adb.org if you have questions or comments with respect to content, or if you wish to obtain copyright permission for your intended use that does not fall within these terms, or for permission to use the ADB logo.

Notes:

In this publication, "\$” refers to United States dollars.

Cover photo from ADB Photo Library (photo by Eric Sales)

Corrigenda to ADB publications may be found at http://www.adb.org/publications/corrigenda.

3

Printed on recycled paper

On the cover: Mangroves serve as a breeding ground for marine biodiversity

(ADB Photo Library/Eric Sales). 


\section{CONTENTS}

Tables and Figures

vi

Minister's Message

viii

Foreword

$\mathbf{x}$

Acknowledgments

xii

Abbreviations

xiii

Introduction

Chapter I Creation of a Project Work Plan

Chapter II Site Preparation

4

Chapter III Planting

Chapter IV Monitoring and Evaluation

Chapter V Project Funding

Glossary

References

47

Appendixes

51 


\section{TABLES AND FIGURES}

\section{TABLES}

1 Site Selection $\quad 4$

$\begin{array}{lll}2 & \text { Reproduction Guide } & 7\end{array}$

3 Dispersal $\quad 7$

4 How Different Substrate Characteristics Influence Species 9

5 Tidal Inundation Classes 11

6 Examples of Stresses to a Mangrove Site 13

7 Examples of Human-Made Stresses and Solutions 14

8 Problems Resulting from Poor Nursery Selection 15

9 Examples of Appropriate Polybag Sizes 29

10 Pest and Disease Control Measures 30

11 A Typical Hardening Process 31

12 Monitoring Phase Activities $\quad 37$ 


\section{FIGURES}

1 A Basic Illustration of Mangrove Zonation 8

2 Zonation and Tidal Patterns 11

3 A Diagram Representing Zonation in Mangroves 12 along the Inundation Levels

4 A Standard Nursery Bed $\quad 17$

5 Typical Layout of the Main Components of a Nursery 18

6 An Example of Project Site Sketch Map 20

7 An Example of Strip Planting Viewed from Above 21

8 An Example of Inverted-V Planting Viewed from Above 22

9 Cluster Planting Viewed from Above 22

10 Harvesting Using a Corer $\quad 25$

11 A Typical Potting Shed for Keeping Substrate Moist 27

12 Cultivating Propagules in a Nursery 27

13 Cultivating Sonneratia seed 28

14 Cultivating Avicennia seed 28

15 Cultivating Xylocarpus Seed 29

16 Correct Planting Depth for Direct Planting of Propagules 33

17 Correct Planting Depth 34

18 Compacting the Substrate Around a Newly Planted Seedling 34

19 Encrusting Barnacles on a Mangrove Sapling 39 


\section{MINISTER'S MESSAGE}

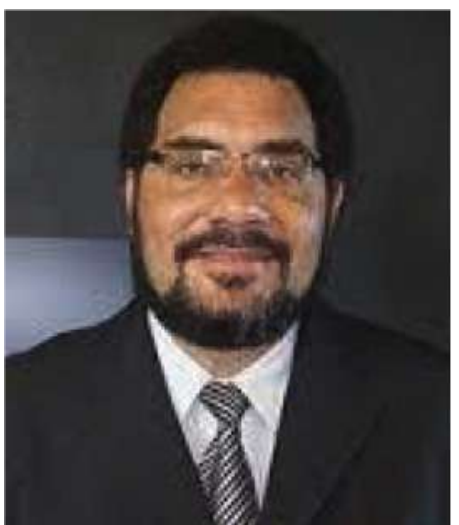

Hon. John Pundari, MBA, OBE, MP
Climate change is here to stay. It has no boundaries and cuts across all sectors of the economy. It is important that adaptation and mitigation measures against climate change must be mainstreamed and implemented through the policies of other sectors, in particular, agriculture, transport, forestry, water resources, land use, and environment.

The issues and challenges of climate change and the strategies to address them clearly complement the national goals of poverty alleviation and sustainable development, as articulated under Pillar 5 of Vision 2050.

There is the political will as indicated by the passing of the Climate Change Management Bill and the establishment of the Climate Change and Development Authority with its own ministry. Papua New Guinea (PNG) is a leader in the region on matters of climate change.

All stakeholders, including government, the private sector, development partners, nongovernment organizations, and civil society must work together to address this emerging issue of climate change. It is a global issue, but the strategies to foster resilience have to be driven by the local communities exposed to the climate change risks.

Adaptation to the adverse effects of climate change is vital to reduce its impacts and increase resilience to future impacts. Coastal flooding and sea surges, among other climate-related risks, are prevalent in most coastal communities throughout PNG.

The cost in terms of casualties and damage to assets resulting from sealevel rise will continue to increase annually unless we initiate cost-effective adaptation measures. It has been identified that mangrove planting and rehabilitation is the most effective and least costly method of coastal defense against rising sea levels. Mangroves not only provide a buffer and hence reduce the intensity or severity of coastal flooding, but also promote ecotourism and serve as a breeding ground for marine biodiversity. 
Our overall adaptation strategy comprises the following:

Firstly, identify, coordinate, and monitor programs and projects that support the development of specific adaptation solutions that protect the country's assets and people against the risk of climate change.

Secondly, reduce climate-related risks in vulnerable communities through an integrated approach that addresses both short- and longterm impacts, hence making climate risk management a part of national development planning.

Thirdly, lead and coordinate climate change adaptation initiatives by consulting and soliciting expert advice from all stakeholders including our development partners, central government line agencies, nongovernment organizations, private sector, and civil society.

Finally, I wish to acknowledge the contribution made by the managing director and his staff from the Adaptation Division of the Climate Change and Development Authority, and the Asian Development Bank through its technical assistance project for the Coral Triangle Initiative (CTI) member countries of the Pacific for assisting with the review and publication of this handbook.

I hope this handbook will become a useful tool for anyone and everyone who wish to take up mangrove planting as a first line of defense against coastal flooding and sea surges.

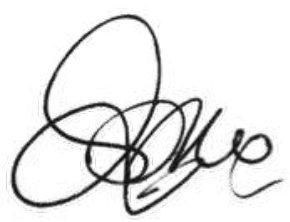

Hon. John Pundari, MBA, OBE, MP

Minister for Environment, Conservation and Climate Change 


\section{FOREWORD}

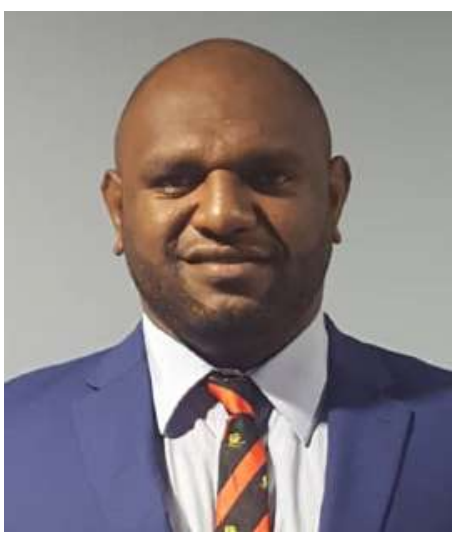

Ruel Yamuna, LLB Managing Director

The Climate Change and Development Authority (CCDA) was established in 2015 through the passing of the Climate Change Management Bill and tasked with a very important developmental function-to deliver on Pillar 5 of Vision 2050 and the Paris Agreement.

This and all other overarching policies support and provide for mainstreaming and committing resources to addressing issues of climate change as a whole of government approach. All stakeholders, including government, the private sector, development partners, nongovernment organizations, and civil society, must work together to address climate change.

The CCDA is tasked with ensuring that Papua New Guinea follows a path of climate-compatible growth and that the country's economy develops while simultaneously mitigating greenhouse gas emissions and reducing vulnerability to climate change risks.

The objective is to ensure that our people build their capacities to be resilient to the risks and impacts of climate change through appropriate adaptation measures to counter extreme weather and climatic events.

Progress has been made to integrate climate change adaptation and risk reduction both at the national policy level and the local level. What has emerged is that, while drawing on international expertise and support, most initiatives and support are targeted at local needs and problems and can be addressed from within - as is often quoted, "think globally but act locally."

Protecting ecosystems, improving farming methods, developing early warning systems, instituting building designs, addressing water excesses and shortages, enhancing public awareness, and promoting education are adaptation/mitigation measures which can be done, and which the CCDA is committed to and is happy to work with everyone. 
This handbook can be used as a tool to advance the Millions of Mangrove Initiative aimed at helping rural communities with the necessary skills to take responsibilities for their actions to protect themselves from increased coastal flooding and sea surges. The handbook is meant to be used in the field. It shows a step-by-step guide, beginning with planning, site analysis, identifying the right species, planting, and ensuring mangrove survival.

It is our hope that this revised handbook is used extensively, and we encourage all stakeholders, particularly our community leaders in coastal communities across Papua New Guinea, to take up mangrove planting as a least cost method of coastal defense.

Finally, I wish to acknowledge all those who contributed toward the review and eventual publication of this handbook, in particular the Asian Development Bank.

I welcome and endorse this revised handbook as a demonstration of our commitment to helping vulnerable coastal communities throughout Papua New Guinea.

God bless Papua New Guinea.

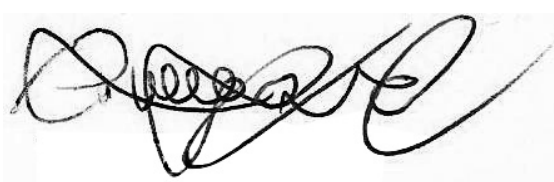

\section{Ruel Yamuna, LLB}

Managing Director, Climate Change and Development Authority 


\section{ACKNOWLEDGMENTS}

This handbook was developed as an activity under the Millions of Mangrove Initiative of the Climate Change and Development Authority (CCDA). The CCDA would like to acknowledge those who contributed significantly to this handbook.

We would like to acknowledge the funding and technical assistance provided by the Asian Development Bank in reviewing and publishing this handbook.

Thank you to our reviewers from the Asian Development Bank and Iki Peter from CCDA.

We also would like to acknowledge the valuable contributions of the following for the original version: Mazzella Maniwavie, marine biologist, Papua New Guinea Marine Programme; Simon Wright, advisor, Adaptation Division, CCDA; Luanne Losi, acting Manager Adaptation, Adaptation Division, CCDA; Ted Mamu, Terrestrial program manager, World Wildlife Fund, Western Melanesian Programme; and Jane Mogina, director, Mama Graun Conservation Trust Fund. 


\section{ABBREVIATIONS}

CBO Community-based organization

cm centimeter

CPG Community Project Group

CPM Community Project Manager

CCDA Climate Change and Development Authority

LEAF Lowering Emissions in Asia's Forests

m meter

$\mathbf{m}^{2}$ square meter

MoM Millions of Mangrove Initiative

NFA National Fisheries Authority

NGO Nongovernment organization

NRI National Research Institute

PNG Papua New Guinea

TNC The Nature Conservancy

WCS Wildlife Conservation Society

WWF World Wide Fund for Nature 


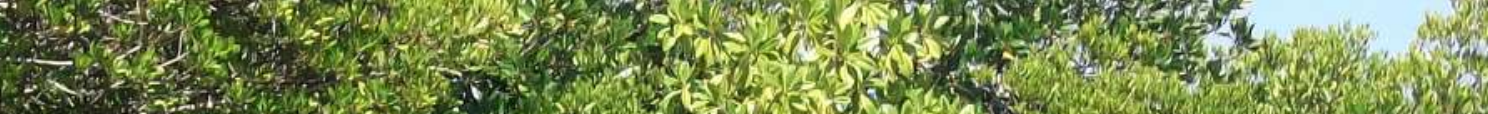

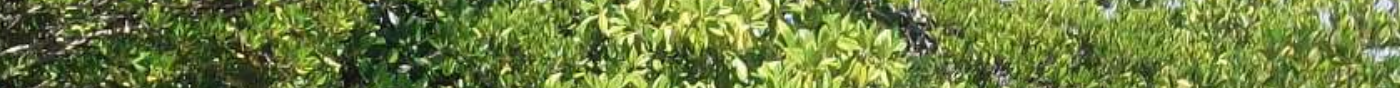

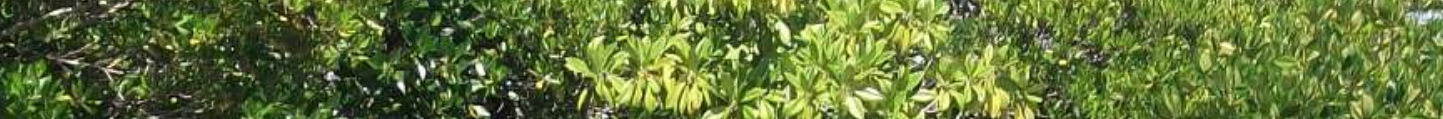
Lit.

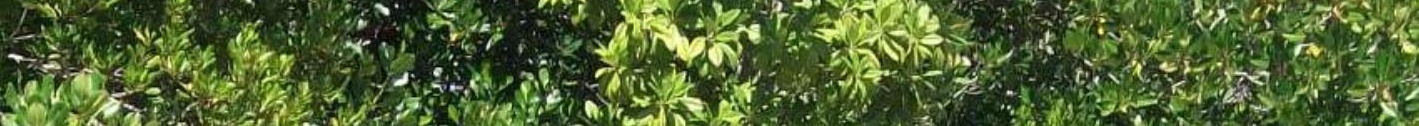

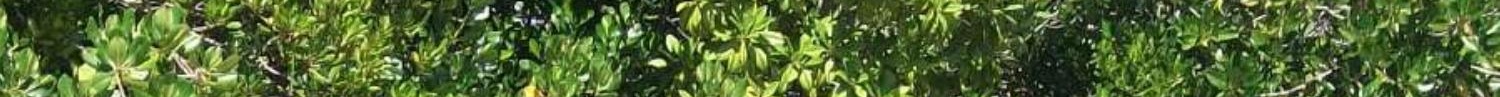

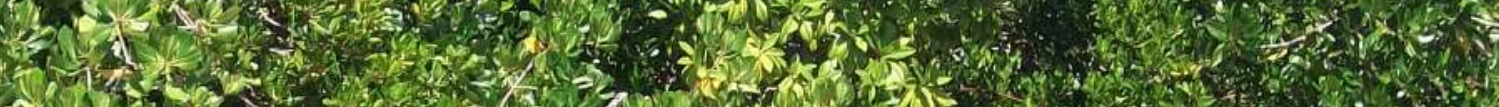

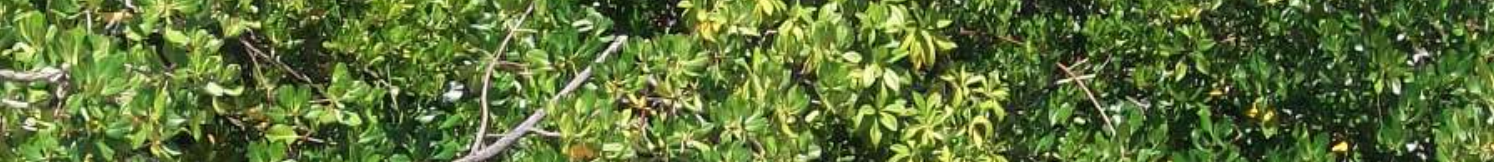
S.

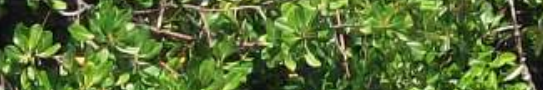

(2) (2) (1)

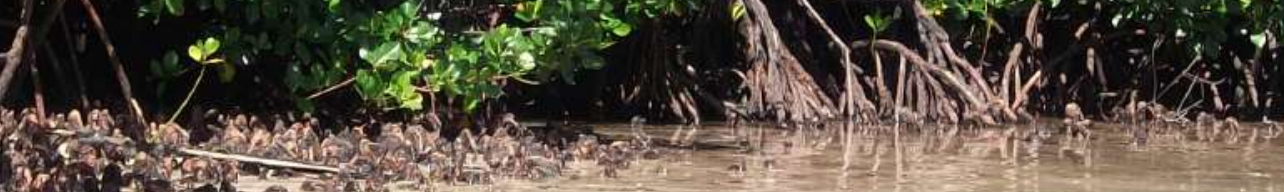

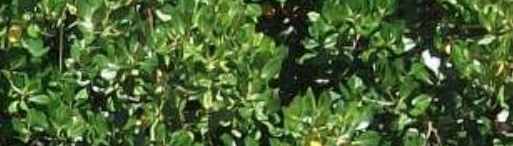
.

2.

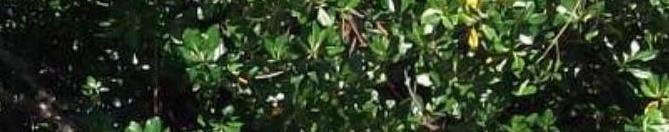

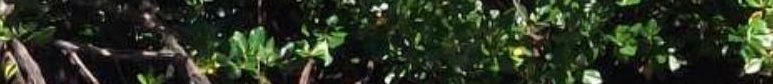

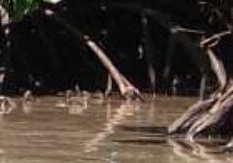
E-

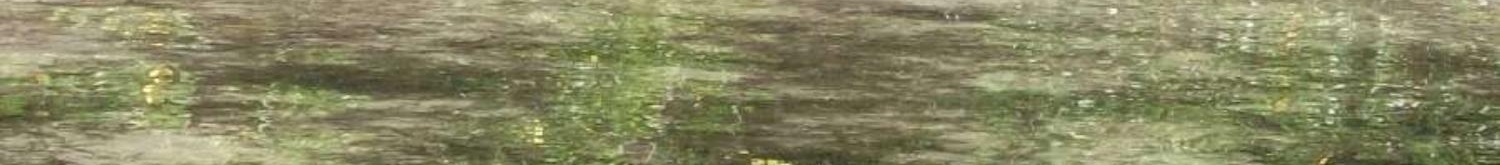

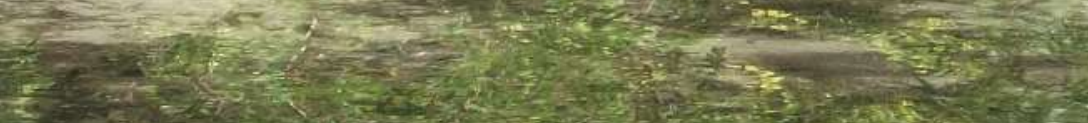

Precious resource. Mangroves line a coastal area in Papua New Guinea (photo by Mazella Maniwavie). 


\section{INTRODUCTION}

In Papua New Guinea (PNG), many coastal communities depend on mangroves for their livelihood. Mangrove trees have been harvested over generations for construction materials and firewood. Mangroves provide a habitat for fish, crabs, shellfish, birds, and reptiles.

Mangroves also provide a natural defense against storm surges, coastal erosion, and coastal flooding. An analysis conducted by government's Climate Change and Development Authority (CCDA) has highlighted community-based mangrove planting as a cost-effective measure for coastal communities. Unfortunately, overexploitation and degradation of mangrove areas means communities are losing this protection.

This handbook is an initiative of the government to address the impacts of climate change. It presents a step-by-step guide on how to rehabilitate mangroves. Although the main purpose is to address coastal flooding, this handbook has been designed to be applicable to planting mangroves for all purposes, including carbon absorption, conservation, fisheries, and ecotourism, among others.

This handbook outlines five activities, including (i) creation of a project work plan; (ii) site preparation; (iii) planting; (iv) monitoring and training; and (v) project funding. 


\section{CHAPTER I: CREATION OF A PROJECT WORK PLAN}

\section{DEFINING GOALS}

The first step is to define project goals. There are four main goals:

(i) Protection of coastal areas. Planting mangroves can reduce shoreline erosion and can protect coastal communities against coastal flooding, high winds and waves, and tsunamis.

(ii) Restoration of a mangrove ecosystem. The aim is to support livelihood without destroying the mangrove forest. This means sustainably harvesting mangrove products such as firewood, timber, and other marine products such as crabs, fish, and shells.

(iii) Conservation of existing mangrove forests. This provides breeding grounds for fisheries and preserving biodiversity. This can be achieved through the creation of protected sites, national parks, nature reserves, and wildlife sanctuaries.

(iv) Carbon absorption (sink). Mangroves absorb more carbon than the other land-based forests.

\section{DEVELOPING A BASIC WORK PLAN}

A workplan' will outline what needs to be done by participants. It will

(i) include all essential tasks, reducing the chance of forgetting or missing a step when activities start;

(ii) break long-term goals into several smaller steps;

(iii) prioritize activities according to their importance and how easy they are to implement;

' See Appendix A for an example of a work plan. 
(iv) assign tasks to individuals or defined groups to make sure no tasks are duplicated and establish clear accountability;

(v) state how individual or defined group performances will be assessed and what the implications of poor performance will be;

(vi) set expectations for project progress and establish a project schedule that can be tracked and monitored; and

(vii) help to develop a budget ${ }^{2}$ and ensure adequate adequate funds are available.

${ }^{2}$ See Table A1 and Table A2 to develop your budget for income and expenses. 


\section{CHAPTER II: SITE PREPARATION}

\section{SELECTING A PROJECT SITE}

There are criteria in identifying and selecting your project site.

Table 1 presents these criteria.

\section{Table 1: Site Selection}

\begin{tabular}{|c|c|}
\hline $\begin{array}{c}\text { First stage } \\
\text { (general project } \\
\text { area) }\end{array}$ & Possible sites \\
\hline $\begin{array}{l}\text { (i) Natural suitability } \\
\text { (can be one or several) }\end{array}$ & $\begin{array}{l}\text { Degraded area-The site is previously a mangrove } \\
\text { area which has been degraded; } \\
\text { Gap-The site is a gap within the nondegraded } \\
\text { stands; } \\
\text { Mudflat-The site is on a mudflat with barrier islands; } \\
\text { River-The site is on an open area along a brackish } \\
\text { river; }\end{array}$ \\
\hline $\begin{array}{l}\text { (ii) Socioeconomic } \\
\text { suitability }\end{array}$ & $\begin{array}{l}\text { Adaptation value-It is expected that the community } \\
\text { will be better protected against coastal flooding after } \\
\text { mangroves have been rehabilitated. }\end{array}$ \\
\hline $\begin{array}{c}\text { Second stage } \\
\text { (specific project site) }\end{array}$ & Possible sites \\
\hline $\begin{array}{l}\text { (i) Natural suitability } \\
\text { (specific) }\end{array}$ & $\begin{array}{l}\text { Natural growth-There are signs of secondary growth } \\
\text { or sparse vegetation with a few mangrove species } \\
\text { growing. } \\
\text { Correct zonation-The site is not submerged by } \\
\text { more than } 1.5 \text { meters in saltwater, as this prevents or } \\
\text { minimizes barnacle infestation. } \\
\text { Sheltered area-There is limited or no exposure to } \\
\text { strong waves, currents, and winds. } \\
\text { Even tides-The tide is such that there is an even } \\
\text { period of inundation and drought. This is a rule of } \\
\text { thumb that varies across species. } \\
\text { Tidal flat-The site is a tidal flat. These areas are best } \\
\text { for expansion of mangrove stands; }\end{array}$ \\
\hline
\end{tabular}




\begin{tabular}{|c|l|}
$\begin{array}{c}\text { Second stage } \\
\text { (specific project site) }\end{array}$ & \multicolumn{1}{c|}{ Possible sites } \\
\hline & $\begin{array}{l}\text { Lack of seagrass-The site is not a seagrass bed; } \\
\text { pests such as crabs and barnacles; }\end{array}$ \\
& $\begin{array}{l}\text { Area of accretion-mangrove seedlings will grow } \\
\text { in areas of soil build up, not in areas that are being } \\
\text { eroded; }\end{array}$ \\
\hline (ii) Socioeconomic & $\begin{array}{l}\text { Conflict of interest-Rehabilitation will not conflict } \\
\text { with existing or future land use and/or development } \\
\text { needs. }\end{array}$ \\
& $\begin{array}{l}\text { Community buy-in-A clear majority of the } \\
\text { community and its leaders support mangrove planting } \\
\text { in the proposed area; }\end{array}$ \\
\hline $\begin{array}{l}\text { Landowner agreement-No individual community } \\
\text { members have a claim to the mangrove area and } \\
\text { oppose rehabilitation. }\end{array}$ \\
\hline
\end{tabular}

Source: Simon Wright \& CCDA Technical Working Group.

After selecting the project site, proceed with the next steps.

\subsection{SITE EVALUATION}

Site evaluation is very important. A successful project can only be carried out if the characteristics and conditions of the site are well understood. The seedlings survival guidelines and actions are adapted from Maniwavie (2012) and from the Mangrove Action Plan's "5-steps to Ecological Restoration of Mangroves" guide.

First, consider the possible survival of seedlings that are going to be planted. This will involve observing certain environmental factors to determine whether your seedlings will have a high or low chance of survival.

Here are some guidelines:

(i) The single most important factor for high mangrove survival is to plant in sites which are not exposed to winds and waves. Mangroves survive best in areas protected from these harsh environments. 
(ii) Mangroves survive better in areas close to forested places, next to land with good soils and streams, or where dead leaves accumulate.

(iii) Mangroves thrive best in places with a mixture of mud and gravel sediments. They do not do well in sandy sediments.

Knowing these information will help you decide where to plant and avoid replanting in problematic sites thus minimizing wasted time, labor, and project funding.

\subsection{FRUITING SEASON}

Understand the patterns of mangrove reproduction: when the seeds and fruits or propagules are produced (flowering or fruiting seasons), and where the seeds and fruits are distributed.

Here are the steps:

(i) Identify which species would naturally occur at your site.

(ii) Ask locals about the species that previously grew on the site.

(iii) Show pictures of species which can make recollection and identification easier and more accurate.

(iv) Conduct a basic survey of the species occurring on or near the site to generate your own information and compare with the local knowledge.

(v) Identify seeds that wash up onto the site.

(vi) Understand the pattern of reproduction of suitable mangroves.

It is important to know when seeds will be available for collection. Use preserved specimens or look at photographs of different mangroves as a guide.

\subsection{RECORDING}

Make a simple record of the type of seeds following Table 2. 
Table 2: Reproduction Guide

\begin{tabular}{|c|c|c|c|c|c|c|c|c|c|}
\hline Species & $\begin{array}{l}\text { Type } \\
\text { of Seed }\end{array}$ & \multicolumn{6}{|c|}{ Months available } & $\begin{array}{c}\text { Indicator } \\
\text { of } \\
\text { Maturity }\end{array}$ & $\begin{array}{l}\text { Size at } \\
\text { Maturity }\end{array}$ \\
\hline \multirow{2}{*}{$\begin{array}{c}\text { Avicennia } \\
\text { marina }\end{array}$} & \multirow{2}{*}{ Propagule } & Jan & Feb & Mar & Apr & May & Jun & \multirow{2}{*}{$\begin{array}{c}\text { Yellow } \\
\text { fruit skin }\end{array}$} & \\
\hline & & Jul & Aug & Sep & Oct & Nov & Dec & & \\
\hline
\end{tabular}

Source: Simon Wright \& CCDA Technical Working Group.

Request for assistance from local officials, nongovernment organizations (NGOs), and others if needed, to fill the table.

It also important to understand the dispersal pattern of suitable mangroves.

The seeds of the various mangrove species near the site will travel in different ways and in different distances. Some may not reach the site. You may also find that seeds from mangroves from another site that make it to your site could be suitable for planting. Use Table 3 below for this purpose.

Table 3: Dispersal

\begin{tabular}{|c|c|c|c|c|c|c|c|c|c|c|c|}
\hline \multirow{3}{*}{$\begin{array}{l}\text { Species } \\
\text { Avicennia } \\
\text { marina }\end{array}$} & \multicolumn{6}{|c|}{ Months available } & \multicolumn{3}{|c|}{$\begin{array}{c}\text { Distance from Site } \\
\text { to Seed Source }\end{array}$} & \multicolumn{2}{|c|}{$\begin{array}{c}\text { *Presence/ } \\
\text { absence of } \\
\text { seeds } \\
\text { at site }\end{array}$} \\
\hline & Jan & Feb & Mar & Apr & May & Jun & \multirow{2}{*}{$\begin{array}{l}0-1 \\
\mathrm{~km}\end{array}$} & \multirow{2}{*}{$\begin{array}{l}1-4 \\
\mathrm{~km}\end{array}$} & \multirow{2}{*}{$5 \mathrm{~km}+$} & \multirow{2}{*}{ Yes } & \multirow{2}{*}{ No } \\
\hline & Jul & Aug & Sep & Oct & Nov & Dec & & & & & \\
\hline
\end{tabular}

$\mathbf{k m}=$ kilometer

Source: Simon Wright \& CCDA Technical Working Group.

Request for assistance from local experts, officials, NGOs, and others if needed, to fill the table.

\subsection{ZONATION}

Zonation refers to the distribution of mangrove species across the intertidal zone.Zonation patterns are characterized by a sequence of plants that occur parallel to the shoreline. 
Here are the steps in determining the zonation:

(i) Identify the zonation of nearby healthy mangroves. This is most useful if these nearby areas resemble the conditions at the chosen site.

(ii) Observe the zonation of mangroves, going from the shore to the land (or terrestrial margin), noting where different species grow.

(iii) Sketch a basic diagram of the zonation pattern, using Figure 1 as an example.

(iv) Use a tape measure to measure how wide the different species zones are and note them down.

\section{Figure 1: A Basic Illustration of Mangrove Zonation}

\begin{tabular}{|l|l|l|l|l|}
\hline Foreshore & Mangrove Front & Mangrove Middle & Mangrove Back \\
Mud, sandy, sandy loam, grav- \\
elly sand, rocky or coral rubble
\end{tabular}

Source: Modified from Whitten et al., 1987. 
Identify the zonation pattern of your mangrove planting site and their distributions and compare this to the substrate pattern of the mangrove area used for your zonation chart.

\subsection{SUBSTRATE OR SOIL TYPE}

Understand the substrate or soil type of the site. The different species of mangroves prefer different types of substrates and knowledge of the substrate type at the site will help determine which species are needed.

Observe the substrate types in the same place where the zonation pattern was observed.

Here are the steps:

(i) Mark the substrate pattern on the zonation chart and note how how it matches up to the zones and species.

(ii) Identify the substrate types on your mangrove planting site and their distribution.

(iii) Compare this to the substrate pattern of the mangrove area used for the zonation chart.

Table 4: How Different Substrate Characteristics Influence Species

\begin{tabular}{|l|l|l|}
\hline Substrate & \multicolumn{1}{|c|}{ Description } & \multicolumn{1}{|c|}{ Typical species } \\
\hline Mud & $\begin{array}{l}\text { A mixture of silt and clay with } \\
\text { organic matter. It can be as shallow } \\
\text { as 2 centimeters (cm) or deeper } \\
\text { than a meter. Avoid mud that smells } \\
\text { very strongly of rotten egg or is so } \\
\text { soft you sink up to your knees into it. }\end{array}$ & $\begin{array}{l}\text { Bruguiera cylindrica } \\
\text { Bruguiera gymnorrhiza } \\
\text { Ceriops tagal } \\
\text { Rhizophora apiculata } \\
\text { Rhizophora mucronata } \\
\text { Rhizophora stylosa }\end{array}$ \\
\hline $\begin{array}{l}\text { Gravelly } \\
\text { sand }\end{array}$ & $\begin{array}{l}\text { A mixture of gravel (pieces of rocks } \\
\text { and stones) and sand. }\end{array}$ & $\begin{array}{l}\text { Avicennia marina } \\
\text { Osbornia octodonta } \\
\text { Sonneratia alba } \\
\text { Rhizophora stylosa } \\
\text { Xylocarpus rumphiana }\end{array}$ \\
\hline $\begin{array}{l}\text { Rocky or } \\
\text { coral rubble }\end{array}$ & $\begin{array}{l}\text { These substrates are generally quite } \\
\text { hard, but with thin layers of }\end{array}$ & $\begin{array}{l}\text { Avicennia marina } \\
\text { Pemphis acidula } \\
\text { sediments. }\end{array}$ \\
& & $\begin{array}{l}\text { Rhizophora apiculata } \\
\text { Shizophora stylosa }\end{array}$ \\
& & \multicolumn{2}{|l}{ Sonneratia alba } \\
\hline
\end{tabular}

Continued on next page 


\begin{tabular}{|l|l|l|}
\hline \multicolumn{1}{|c|}{ Substrate } & \multicolumn{1}{|c|}{ Description } & \multicolumn{1}{c|}{ Typical species } \\
\hline Sandy & $\begin{array}{l}\text { Sandy substrates normally } \\
\text { consist of very small grains of } \\
\text { rock, shell and coral with little } \\
\text { or no organic matter. Like mud, } \\
\text { sand may be as shallow as 2-3 } \\
\text { cm or as deep as several meters. }\end{array}$ & $\begin{array}{l}\text { Osbornia octodonta } \\
\text { Rhizophora apiculata } \\
\text { Rhizophora stylosa } \\
\text { Sonneratia alba }\end{array}$ \\
\hline Sandy loam & $\begin{array}{l}\text { A mixture of clay, silt, sand and } \\
\text { organic matter. }\end{array}$ & $\begin{array}{l}\text { Avicennia marina } \\
\text { Rhizophora apiculata } \\
\text { Rhizophora stylosa } \\
\text { Sonneratia alba } \\
\text { Sonneratia caseolaris }\end{array}$ \\
\hline Muck & $\begin{array}{l}\text { Similar to mud except that it } \\
\text { contains more organic matter } \\
\text { than mud. It also tends to be } \\
\text { deeper, starting at more than } \\
\text { 10 cm thick up to a few meters. } \\
\text { Like mud, muck may have the } \\
\text { same foul, rotten egg smell; } \\
\text { if so, planting should not be } \\
\text { attempted. }\end{array}$ & $\begin{array}{l}\text { Bruguiera gymnorrhiza } \\
\text { Ceriops australis } \\
\text { Ceriops tagal } \\
\text { Rhizophora mucronata }\end{array}$ \\
\hline
\end{tabular}

Source: C.D. Field. 1996. Restoration of Mangroves Ecosystems.

\subsection{TIDES}

The tide is the single most important factor in establishing a successful mangrove restoration project. Understand the normal patterns that control the distribution and growth of mangroves in the area. Know how deep the tide submerges the site.

Here are the steps:

(i) Go to the site elected and monitor the tides;

(ii) Observe the limits of the high tides and low tides during a full moon or new moon. These are the "spring tide" water marks; 
(iii) Observe the limits of the high tides and low tides during a half moon. These are the "neap tide" water marks. Average sea level is between the neap tide high and low water marks. Add the different tide water marks to the zonation sketch, such as in Figure 2 below.

\section{Figure 2: Zonation and Tidal Patterns}

Extreme tide high water

Spring tide high water

Neap tide high water

Average sea level

Neap tide low water

Source: Whitten et al. 1997.

(iv) Understand the duration and frequency of the tides affecting the site. Monitor the duration of the tides and record how many hours each zone of mangroves is submerged by water and how long the zones are dry.

(v) Monitor how often the tide reaches a certain level each month and fill a matrix similar to Table 5. For example, if all high tides of the site reach at least $\mathrm{O}$ and $2.4 \mathrm{~m}$, then the flooding frequency of tides between $\mathrm{O}$ and $2.4 \mathrm{~m}$ is 56-62 times (i.e., 2 high tides per day $\times 31$ days per month $=62$ times per month).

Table 5: Tidal Inundation Classes

\begin{tabular}{|c|c|c|c|}
\hline Class & $\begin{array}{c}\text { Type of Tides that } \\
\text { are Flooded By }\end{array}$ & $\begin{array}{c}\text { Height Above } \\
\text { Average Low Tide }\end{array}$ & $\begin{array}{c}\text { Flooding Frequency } \\
\text { (Times Per Month) }\end{array}$ \\
\hline 1 & All high tides & $0-2.4 \mathrm{~m}$ & $56-62$ \\
\hline 2 & Medium high tides & $1-3.4 \mathrm{~m}$ & $45-59$ \\
\hline 3 & Normal high tides & $3.4-4 \mathrm{~m}$ & $20-45$ \\
\hline 4 & Spring tides & $4-4.6 \mathrm{~m}$ & $2-20$ \\
\hline 5 & Extreme tides & Higher than $4.6 \mathrm{~m}$ & 2 \\
\hline
\end{tabular}

$\mathbf{m}=$ meter

Source: Watson, 1928. 
The zonation chart should look something like Figure 3. This will be a valuable reference tool for future activities.

\section{Figure 3: A Diagram Representing Zonation in Mangroves along the Inundation Levels}

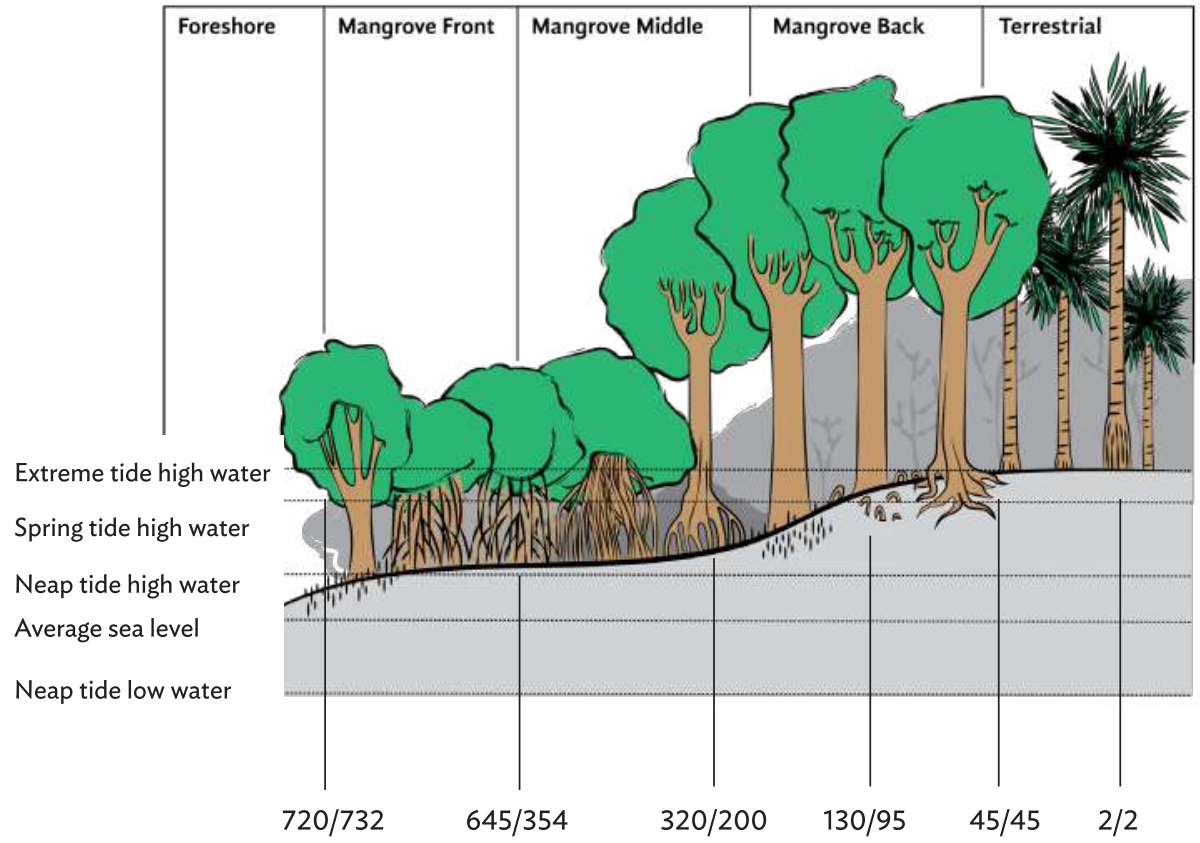

Source: Modified from Whitten et al. 1987.

\subsection{DISTURBANCES}

If the project site used to be covered by mangroves but is now barren, it is necessary to understand what led to the degradation and what is preventing recovery. Disturbances that cause mangrove degradation can be classified according to whether they are natural (caused by tides) or human-made.

Here are the steps to determine disturbances:

(i) Identify the causes of degradation of the mangrove site. Look at Table 6 for a list of the most common stresses responsible for mangrove losses, and note which of these are relevant to the site and other nearby mangrove areas.

(ii) Determine when the different stresses began or occurred, and when the mangroves began to degrade. 
(iii) As a general rule, the closer together the start of the stress and the start of the degradation, the more likely it is that one caused the other.

\section{Table 6: Examples of Stresses to a Mangrove Site}

\begin{tabular}{|l|l|}
\hline \multicolumn{1}{|c|}{ Natural } & \multicolumn{1}{c|}{ Human-made } \\
\hline $\begin{array}{l}\text { River mouth blocked by sandbank } \\
\text { preventing water flow }\end{array}$ & $\begin{array}{l}\text { Soil is hypersaline and too acidic } \\
\text { usually after intensive farming }\end{array}$ \\
\hline $\begin{array}{l}\text { Drought leading to lack of fresh water or } \\
\text { groundwater }\end{array}$ & $\begin{array}{l}\text { Drains, ditches, or dikes that divert } \\
\text { fresh water away from mangroves } \\
\text { (e.g. aquaculture ponds) }\end{array}$ \\
\hline $\begin{array}{l}\text { Floods leading to too much salt or } \\
\text { fresh water }\end{array}$ & $\begin{array}{l}\text { Roads cutting through mangroves } \\
\text { without drainage preventing } \\
\text { water flow }\end{array}$ \\
\hline Ongoing storm surge (or cyclone) & $\begin{array}{l}\text { Domestic animals damaging } \\
\text { seedlings }\end{array}$ \\
\hline $\begin{array}{l}\text { Soil is hypersaline and too acidic usually } \\
\text { after intensive farming }\end{array}$ & \\
\hline
\end{tabular}

Source: Simon Wright \& CCDA Technical Working Group.

\subsection{REMOVAL OF STRESSES}

Once the stressors have been determined, take action to restore natural growth and change community habits to reduce human-made destruction.

Here are the guidelines:

(i) Focus on the artificial stresses at this stage of the project. There is not much to do to alter most natural hazards.

(ii) Prioritize solutions that can be made at once, rather than those that take time. For instance, modifying constructions, such as putting a drain under a road, can be quick and have immediate impact.

(iii) Use Table 7 as a reference of possible solutions to human-made stresses, but note that this does not contain all possible stresses or solutions.

(iv) Use your knowledge of the community and environment to identify other stresses and come up with solutions. Engage the help of community members. 
Table 7: Examples of Human-Made Stresses and Solutions

\begin{tabular}{|l|l|}
\hline \multicolumn{1}{|c|}{ Stress } & \multicolumn{1}{|c|}{ Solution } \\
\hline $\begin{array}{l}\text { Domestic animals damaging } \\
\text { seedlings e.g. pigs foraging }\end{array}$ & $\begin{array}{l}\text { Put up a fence to stop animals roaming } \\
\text { the mangrove area. }\end{array}$ \\
\hline $\begin{array}{l}\text { Overconsumption of propagules } \\
\text { for food }\end{array}$ & $\begin{array}{l}\text { Create and implement community laws to } \\
\text { institute closure periods and/or harvesting } \\
\text { limits and restrict access to certain sites or } \\
\text { create a mangrove management plan. }\end{array}$ \\
Provide alternative crops.
\end{tabular}

Source: Simon Wright \& CCDA Technical Working Group.

\section{CONSTRUCTING A NURSERY}

The need for nurseries depends on the species to be grown and the environmental conditions of the site. Mangroves with large seeds or fruits, such as rhizophora, can be planted directly into the substrate without spending time in a nursery. Direct planting is considerably cheaper and easier than having a nursery phase and planting from polypots or polybags.

However, research has shown that an initial growth phase in a nursery tends to improve the chances of seedling survival, especially where the substrate is unstable or the seeds are small. 
Note that constructing nurseries has its own challenges, as shown in Table 8.

Table 8: Problems Resulting from Poor Nursery Selection

\begin{tabular}{|c|c|}
\hline Problems & Likely reason \\
\hline $\begin{array}{l}\text { High mortality due to } \\
\text { under-watering. There is no } \\
\text { balance between the amount of } \\
\text { fresh water and saltwater. }\end{array}$ & $\begin{array}{l}\text { No nearly freshwater source or saltwater } \\
\text { source }\end{array}$ \\
\hline High mortality due to flooding. & $\begin{array}{l}\text { Nursery area exposed to high rainfall } \\
\text { run-off or placed in wrong tidal range. }\end{array}$ \\
\hline $\begin{array}{l}\text { High mortality due to low level } \\
\text { of care } \\
\text { Loss of plants from theft }\end{array}$ & Nursery is too far from village. \\
\hline $\begin{array}{l}\text { High mortality due to lack of } \\
\text { proper substrate for potting }\end{array}$ & $\begin{array}{l}\text { Nursery is too remote from a proper source } \\
\text { of appropriate potting substrate. }\end{array}$ \\
\hline $\begin{array}{l}\text { High mortality due to } \\
\text { overcrowded plants }\end{array}$ & $\begin{array}{l}\text { Nursery is too small for the number of } \\
\text { plants being grown. }\end{array}$ \\
\hline $\begin{array}{l}\text { High mortality due to long } \\
\text { transport distance to planting area }\end{array}$ & Site is not centrally located. \\
\hline High mortality due to pests & $\begin{array}{l}\text { Nursery site placed at intertidal area that is } \\
\text { infested with pests }\end{array}$ \\
\hline
\end{tabular}

Source: Simon Wright \& CCDA Technical Working Group.

Care should be taken to follow the necessary steps so that the nursery is successful and the seedlings transferred to the site are healthy and ready for the possibly harsh natural conditions at the restoration site.

\subsection{NURSERY SITE SELECTION}

Water supply is critical, as well as its location and availability.

Here are guidelines for the water supply:

(i) Place the nursery where it can get some some saltwater and some fresh water. Set it up near the sea where it will be periodically submerged by tides or a river, but make sure that it is not vulnerable to strong flooding.

(ii) Construct the nursery where it is easiest to get water, materials, and mangroves. 
(iii) Consider the distance from planting site to the houses of those working at the nursery; the closer the nursery is to houses, the more likely it is that daily activities will take place. However, make sure the site is monitored closely, as the closer the nursery is to households, the more it is exposed to disturbances from children and animals.

(iv) If possible, the nursery site should be an existing open area to avoid the cutting of trees. It is ideal to have some trees in the nursery to shade some areas of the nursery. Leaves and twigs from removed vegetation can be used to start compost beds.

(v) For good drainage, select a site that drains well and is relatively flat and shallow. Plants will die if they are always submerged in water.

(vi) Use standard dimensions when calculating the area needed for the nursery.

(vii) Create sections to use as nursery beds or to hold seedlings in polypots or polybags. Alternatively, use bamboo or dead banana stems.

\subsection{NURSERY BEDS}

Here are guidelines for the nursery bed:

(i) A standard nursery bed is 10 meters $(\mathrm{m})$ long and $1 \mathrm{~m}$ wide. The number of beds needed depends on how many seedlings need to be planted. For example, if the selected species is Rhizophora stylosa and the polypots are 20 centimeters $(\mathrm{cm})$ in diameter, get five (5) polypots to a meter (Figure 4). In a $10 \mathrm{~m} \times 1 \mathrm{~m}$ space, at least $50 \times 5$ polypots can fit, which means 250 seedlings.

(ii) If you want to plant 1 hectare at a density of 1 seedling per square meter, you need 10,000 seedlings. This would mean you need 40 nursery beds (10,000 seedlings/250 nursery beds).

(iii) Nursery beds are usually $1 \mathrm{~m}$ apart.

(iv) Have an additional area of roughly 100 square meters (m2) for potting area, equipment storage, germination and hardening beds, and a loading zone for boats and/or vehicles. 
All these details together ( $40 \times 10 \mathrm{~m}^{2}$ for nursery beds, $40 \times 10 \mathrm{~m}^{2}$ for gaps between beds, $100 \mathrm{~m}^{2}$ as a general working area) add up to $900 \mathrm{~m}^{2}$. Reduce the area if it is too large. Use smaller polybags.

\section{Figure 4: A Standard Nursery Bed}

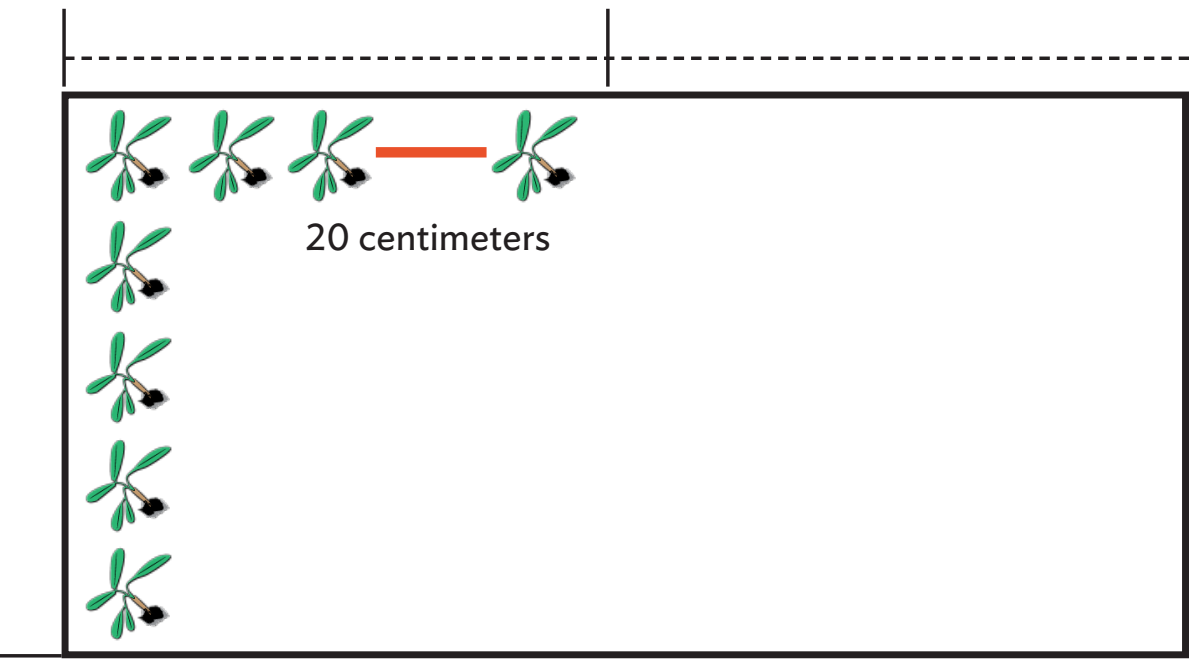

Source: Mazella Maniwavie.

\subsection{DESIGNING A NURSERY}

There are several steps in designing a nursery:

(i) Identify workers. They will constitute the community project group (CPG). The CPG must decide who will be responsible for all the phases of the project. Up to ten (10) people may be needed.

(ii) Determine the boundary.

(iii) Sketch a map showing the boundary of the nursery area, the shape of the area, and the approximate lengths of each side. Take note of how many seeds are needed.

(iv) Lay out the nursery as a square or rectangle.

(v) Develop your nursery plan and carefully consider what goes where.

(vi) Plan how to get seeds in and seedlings out (by foot, boat, or truck) and secure the requirements. 
Figure 5:Typical Layout of the Main Components of a Nursery

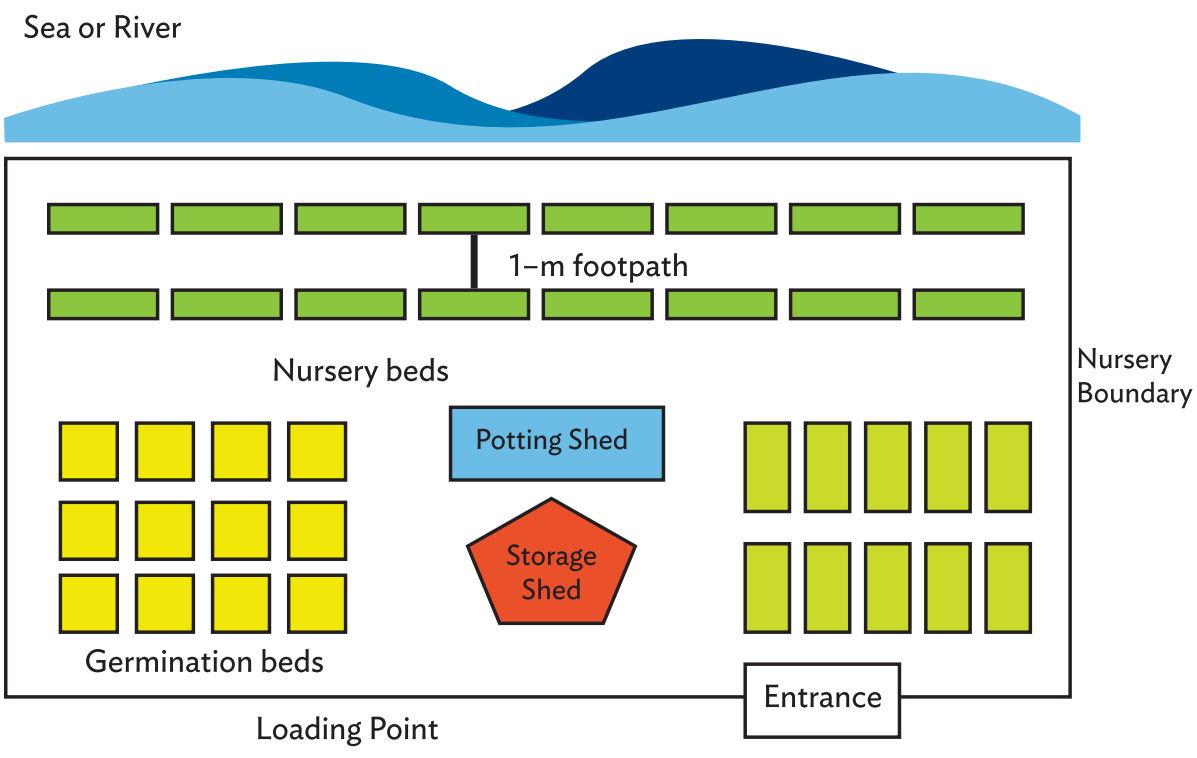

\subsection{BUILDING THE NURSERY}

This will probably require the whole CPG or more. The activities include, but are not limited to,

(i) buying the materials;

(ii) transporting materials and workers to the site;

(iii) buying or borrowing tools (shovels, hammers etc.); and

(iv) levelling the site by digging the high levels and putting the substrate in the low spots.

Once clearing and levelling have been completed, the nursery should be laid out using the prepared map. Mark out the various parts of the nursery and begin construction.

\subsection{SEED GERMINATION BEDS}

These are $10 \mathrm{~m} \times 1 \mathrm{~m}$ beds raised slightly $(5 \mathrm{~cm}$ to $10 \mathrm{~cm}$ ) above the level of the surrounding area, higher than nursery beds. Use these beds to germinate small seeds before transplanting to polybags. 
Here are the guidelines:

(i) For mangroves such as Xylocarpus spp., Bruguiera cylindrica, and Heritiera litoralis, raise the beds at least $30 \mathrm{~cm}$ to $50 \mathrm{~cm}$ above the level of surrounding area and locate at the row parallel to the land.

(ii) Raise the area either by bringing in substrate to each bed or by digging out the substrate from a $40 \mathrm{~cm}$ wide area immediately next to the beds.

(iii) Keep the substrate from spreading by lining each bed with timber strips/wood, rocks, or bamboo curb. Concrete blocks can be used but are expensive.

(iv) When planting species with small seeds, sow them in seedbeds and not directly into polypots or polybags. Wait for these seeds to germinate and when they are about $5 \mathrm{~cm}$ tall, carefully move them into polypots or polybags.

(v) Keep the soil around the roots when you transplant them. Use a thin stick to dig holes in the polybags before transplanting the seedlings.

\subsection{POTTING SHEDS}

Potting sheds can be made out of nipa or coconut leaves. Typically larger than $3 \mathrm{~m} \times 4 \mathrm{~m}$ in area, they are built with three walls; and instead of a door, a fourth wall is kept open. Bagging and storage sheds should also be constructed with doors that can be locked.

\subsection{POTTING SUBSTRATE}

Collect substrate from the future planting area or a similar area that is suitable for the mangroves. To minimize the potential negative impact on the site, only remove as much soil as needed.

\subsection{HARDENING BEDS}

The hardening beds will be used to harden off seedlings before planting. The hardening bed is constructed with the same design as the nursery beds. Roofing over the hardening beds can be made from nipa leaves and supported by $1.5 \mathrm{~m}$ poles.

\section{GATHERING SEEDS}

Review all the information and work out what species are needed, how many are needed, and when they can be collected. 
Here are the guidelines:

(i) Decide which seeds are needed. This is one of the key decisions to be made, and there are several ways to go about it.

(ii) Refer to the mangrove information in sheet provided (Appendix 1, Table A1.4) and use the information collected in the previous sections.

(iii) If multiple species are suitable for each zone, choose the species that best meets the goals of the project by answering the following questions:

(a) Which species is the easiest to collect?

(b) When do I want to collect seeds?

(c) When do I want to plant the seeds?

(d) Which species do I prefer for their resources benefit

(e.g., food, medicine, wood, etc.)

(iv) Engage an expert. While the decision of where to plant mangroves and what species to focus on can be made using information within this handbook, engaging an expert from a nongovernment organization (NGO), university, or CCDA can help you decide. Contact NGOs and local government for assistance.

(v) If multiple species are suitable for each zone, choose the species that best meets the goals of your project by asking yourself questions such as:

(a) Which species is the easiest to collect?

(b) When do I want to collect seeds?

(c) When do I want to plant the seedlings?

(d) Which species do I prefer for their resources benefits (e.g. food, medicine, timber, etc.)?

Figure 6: An Example of Project Site Sketch Map
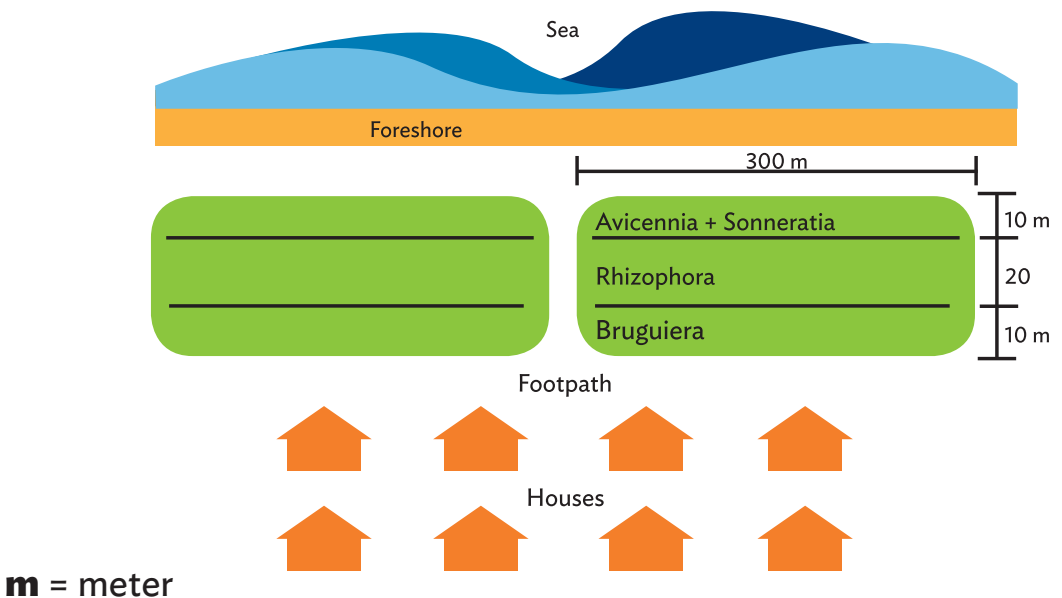

meter

Source: Mazella Maniwavie. 


\subsection{CHOOSE A PLANTING PATTERN}

There are several planting patterns that can be used to plant mangroves, each with its own particular benefits. Most mangrove planting efforts distribute the mangroves evenly across the site.

The three common patterns are as follows:

(i) Strip planting. The traditional way of planting mangroves can be used for all site types. Plant seedlings in rows, equally spaced from each other. If the site is protected from waves and wind, plant using normal spacing. If the site faces medium to high winds or waves, decrease spacing between seedlings.

If seedlings were planted close together and are doing well after 2 years, some seedlings may need to be transplanted to increase the space between shrubs or trees.

\section{Figure 7: An Example of Strip Planting Viewed from Above}

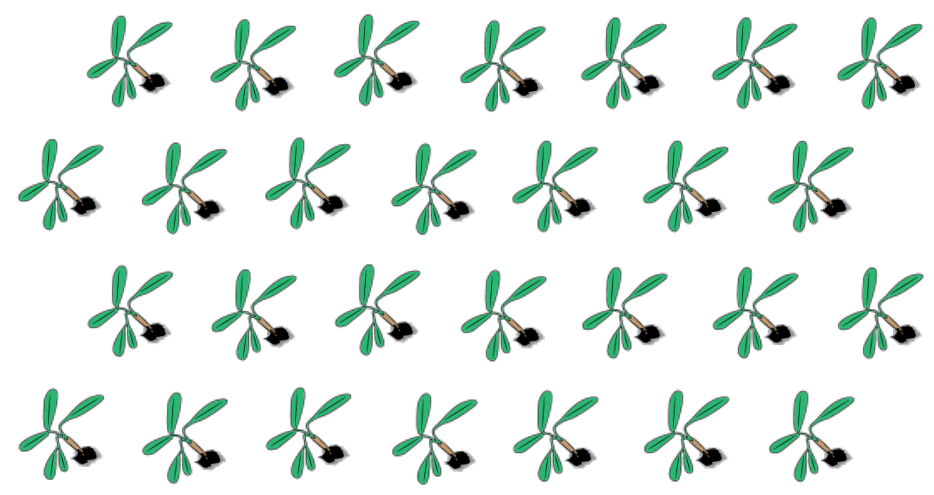

Source: Mazella Maniwavie.

(ii) Inverted V planting. This is suitable for sites facing moderate wave or winds. Space seedlings at between $25 \mathrm{~cm}$ and $50 \mathrm{~cm}$ apart in $\mathrm{V}$-shaped groups of about 11 seedlings per group.

Plant so that the point of the $V$ faces the sea to deflect wave impact. Space each $V$ between $1 \mathrm{~m}$ and $1.5 \mathrm{~m}$ from each other. If all seedlings in the $\mathrm{V}$ pattern are growing well after 2 years, transplant them to where there are gaps. 


\section{Figure 8: An Example of Inverted-V Planting Viewed from Above}

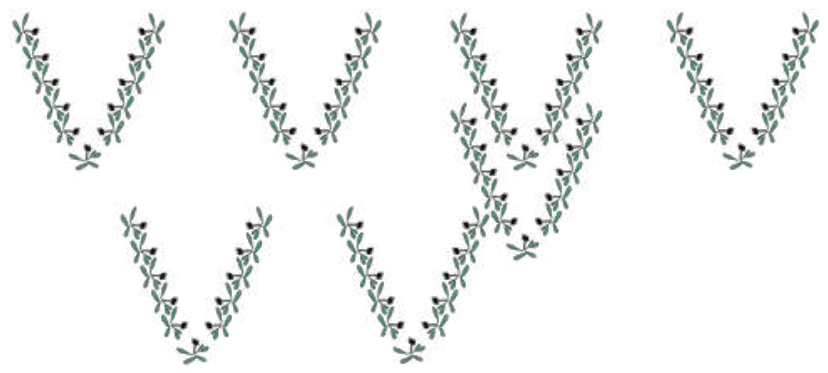

Source: Mazella Maniwavie.

(iii) Cluster planting. This is suitable for sites facing strong waves or winds. Space seedlings at between $25 \mathrm{~cm}$ and $50 \mathrm{~cm}$ apart in small clusters, about 10 seedlings per cluster. Space each cluster between $1 \mathrm{~m}$ and $1.5 \mathrm{~m}$ away from the next one.

\section{Figure 9: Cluster Planting Viewed from Above}

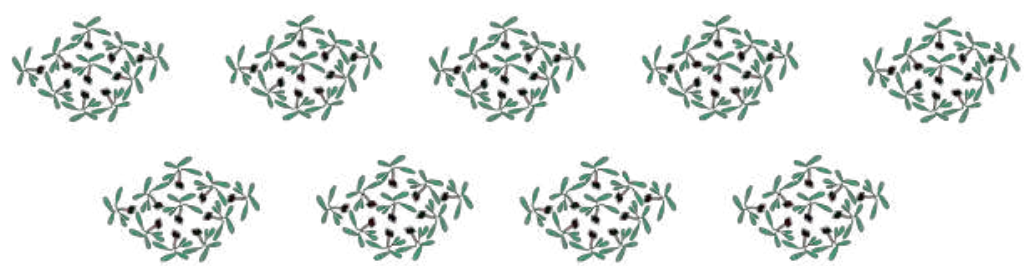

Source: Mazella Maniwavie.

If all seedlings in the cluster are growing well after 2 years, transplant them where there are gaps.

\subsection{DETERMINING HOW MANY SEEDS ARE NEEDED}

Sketch a map of the project site. It does not have to be exact, but it should be clear enough to provide guidance on the location of human and animal paths, intended planting blocks, and seedling density.

Here are the guidelines in determining how many seeds are needed:

(i) Calculate how many seedlings are needed and how much space each seedling will require. For example, if spaced at $25 \mathrm{~cm}$ apart, each seedling will take up $0.25 \mathrm{~m} \times 0.25 \mathrm{~m}=0.0625 \mathrm{~m}^{2}$, or if spaced $2 \mathrm{~m}$ apart, they take up $2 \mathrm{~m} \times 2 \mathrm{~m}=4 \mathrm{~m}^{2}$ in area. 
(ii) Determine the proportions of the zones and then calculate the area of each zone. This will be easier if the zones are rectangular, e.g. if the total site is $1,000 \mathrm{~m}^{2}$ and half is going to be for Rhizophora mucronat, then the proportion will be $50 \%$ and the area for that zone will be $50 \% \times 1000 \mathrm{~m}^{2}=$ $500 \mathrm{~m}^{2}$.

(iii) Divide the area of each zone by the area needed for each species to get the number of seedlings required per zone. For example, if the species being planted requires $2 \mathrm{~m}^{2}$ per seedling and the zone for that species is $800 \mathrm{~m}^{2}$, you will need $800 / 2=400$ seedlings to fill the area.

(iv) Estimate how many seedlings will survive the nursery phase (e.g., $80 \%$ will survive). Now divide the seedlings needed for planting by the expected survival rate. For example, if you need to plant 100 seedlings and the survival rate is expected to be $80 \%$, then $100 / 0.8=125$ seedlings need to be raised, i.e., 25 more than you need to plant.

(v) Estimate how many seedlings are expected to fail after planting at the site every year. After you have planted the seedlings in year 1, collect and grow enough seeds to replace the expected failures. For example, if you planted 1,000 seedlings and $90 \%$ is expected to survive, replace the $10 \%$ that is expected to die. In year 2, plant 1,000 x 10\% = 100 seedlings. If failures are expected in the nursery, grow even more.

(vi) Repeat the replacement planting process until over $80 \%$ of seedlings planted are alive and growing. For example, if 100 seedlings were planted in year one and 50 die (50\%), plant 50 replacements in year 2. If $25(50 \%)$ die through year 2, plant 25 replacements in year 3 .

\subsection{COLLECTING SEEDS}

Now that you know how many seeds to plant on a yearly basis, it is time to collect the seeds.

Here are the guidelines:

(i) Identify the appropriate timing of collection. Most species only produce seeds for a few months a year while others produce year-round so collecting propagules and seeds at the right time is critical. Timing will vary from region to region. When fruiting season begins, start looking for seedlings washing up on shore. You will likely need to make several trips over the course of a few weeks to get enough propagules. 
(ii) Prepare the collection team. Decide whether a small or large group is needed. Decide on the number of people needed for collecting based on the availability of quality seedlings in the collection area. You may also look for volunteers and train them.

(iii) Use pictures of trees and seeds to collect and teach people how to collect healthy, ripe seeds without damaging the trees or mangrove floor. The team should take large bags to store the collected seeds.

(iv) Collect seeds and propagules from the shore or under mature healthy trees, not directly from trees. Though collecting from trees may be easier, it is likely that the seeds from the trees are not yet mature and you might also damage the trees.

(v) If, however, you do choose to harvest propagules from wild trees, collect propagules/seeds from healthy mature trees, i.e., trees less than 5 years old. The most harvested are propagules from rhizophora species which when ripe have a distinct yellow/reddish collar. Propagules are easily released from the cap when harvested from the tree (see Table A1.5).

(vi) When collecting from the shore, only select healthy, good quality seeds and propagules. Select seeds that are free from physical damage.

(vii) Ball and core seeds from wildings (young saplings between $0.5 \mathrm{~m}$ and $1 \mathrm{~m}$ tall) if there are not enough seeds or propagules in the area. Wildings are collected either by "balling" with a spade or by "coring" with a corer.

Balling involves inserting the blade of the spade into the soil at the appropriate distance from the wilding and lifting up the chunk of soil containing the wilding. Gently wrap mud around the root ball and wrap the ball in plastic or some other material (e.g., banana leaf) so that the soil is kept intact and the roots are not exposed during transportation.

A corer can be constructed from hollow steel pipes (usually $10 \mathrm{~cm}$ in diameter and $30 \mathrm{~cm}$ long). The corer should have a serrated edge at bottom. Slide the corer over the seedling and push the corer into the ground in a spiral motion. Lift the corer out and carefully shake it to release the plug of soil carrying the wilding. Wrap the plug in plastic or some other material (e.g., banana leaf) so that the roots are not exposed. Place the seedlings in wooden trays to keep them intact when transporting (see Figure 10). 
Figure 10: Harvesting Using a Corer

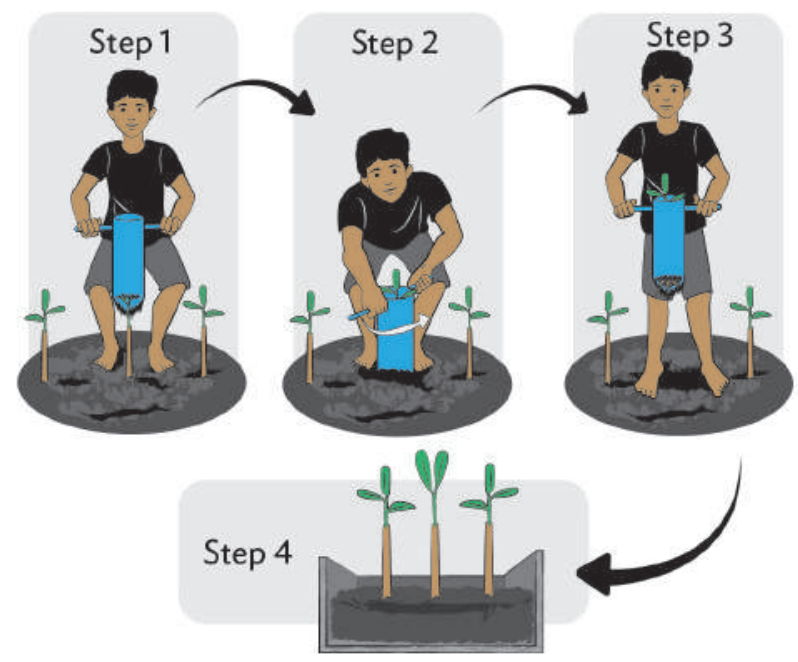

Source: Mazella Maniwavie.

Whether balling or coring, the seedlings should be potted at the nursery or planted on site as soon as possible and not more than a day after collection.

\subsection{SORTING AND TRANSPORTING SEEDS}

Here are some guidelines:

(i) Propagules can be packed in bundles of 50 or 100. Make bundles from palm or banana leaves to keep the propagules moist.

(ii) Small seeds should be transported in rice or copra bags with a moist cloth placed on top of each bag. Be sure to keep the cloth moist throughout the trip and do not expose the materials to direct sunlight. Open baskets made from palms are also suitable.

(iii) Wildings should be transported on trays or in large flat-bottom containers such as plastic crates. Keep each root ball wrapped and do not pack wildings too tightly. Otherwise, you could damage their roots. Keep the wildlings moist and protect them from the sun with banana or palm leaves to prevent them from drying out.

(iv) If transporting by boat or by truck, protect the seedlings with a canvas or some coconut fronds. 


\section{OPERATING AND MANAGING A NURSERY}

\subsection{STORAGE}

Between collection and propagation, the seeds and propagules must be prepared for planting or storage.

Here are some guidelines:

(i) Allow small seeds to air-dry prior to storing. You can spread them on banana leaves or copra bags under a tree shade. Aim for a dry seed coat.

(ii) Place the air-dried seeds in plastic bags, seal the bags, and store at room temperature. Note that some seeds do not like drying or cool temperatures and too much shade.

(iii) Propagules may be kept under shade for as long as 2 weeks, but avoid placing them on the ground or any moist surface.

(iv) Do not store too many seeds in one big basket, as heat may be generated and kill the seeds.

(v) Open baskets are best for storage.

\subsection{PROPAGATION AND GERMINATION}

The following activities are needed to germinate seeds and propagules:

\subsubsection{PREPARATION OF POTTING SUBSTRATE}

The growth of seedlings in the nursery significantly depends on the quality of the potting mix soil. Fast root development is enhanced when the potting substrate is porous, i.e., substrate allows water to drain out. If possible, use a sandy-loam substrate (mixture of sand and mud) that is high in organic matter.

Prepare potting substrate in advance to avoid unnecessary delays which can result in high seedling mortality, especially for wildings. It is recommended to prepare potting substrate of several cubic meters and have it on hand at all times. 
Figure 11: A Typical Potting Shed for Keeping Substrate Moist

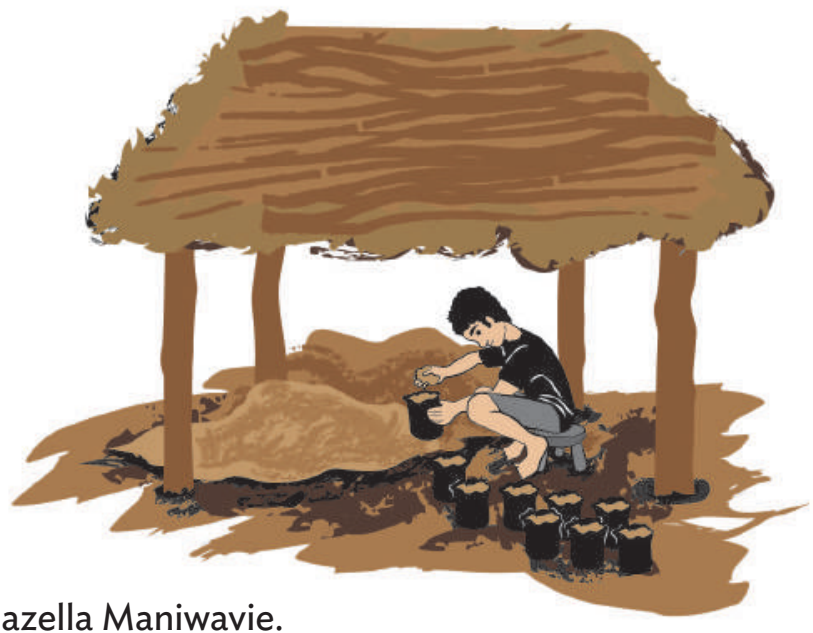

Source: Mazella Maniwavie.

\subsubsection{GERMINATION TECHNIQUES}

Certain species with propagules that are about $15 \mathrm{~cm}$ long can be successfully sown directly into the substrate of sites that are well protected from winds and waves. On sites that are exposed to winds and waves, it is best to raise the propagules in polybags or bamboo in a nursery before transplanting to degraded sites.

Some of the major groups ideal for transplanting directly to the field include rhizophora, ceriops, and bruguiera.

The illustration below gives you an idea of how propagules can be germinated in polybag for cultivation in a nursery.

Figure 12: Cultivating Propagules in a Nursery

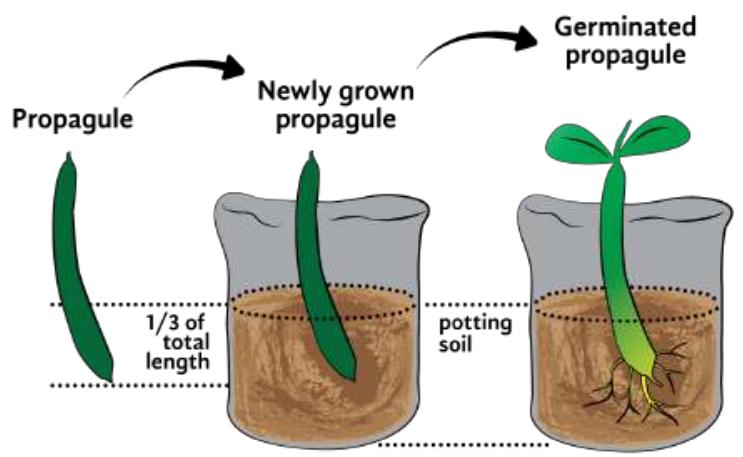

Source: Mazella Maniwavie. 
Here are guidelines on germination:

(i) Sow these boomerang-shaped seeds in a seed box/seedbed with sandy substrate.

(ii) Bury half of the seed with the curved portion up. Figure 13 shows how species with small to medium sized seeds can be germinated.

(iii) For early and uniform germination, soak the fruit in fresh water for 7 days and then sow the seeds.

Figure 13: Cultivating Sonneratia Seed

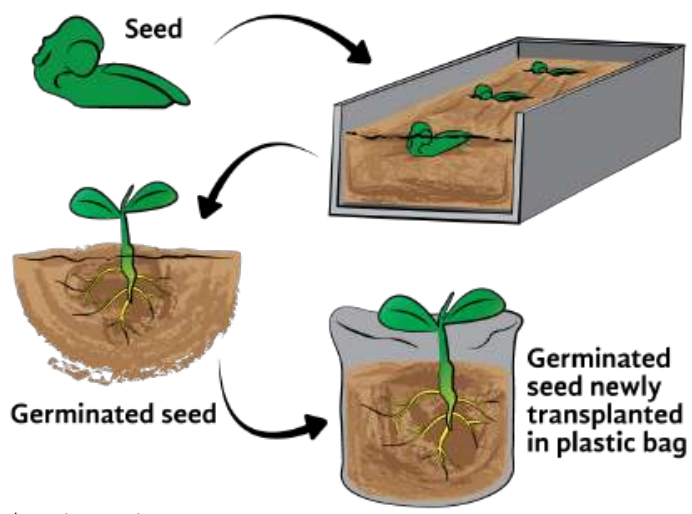

Source: Mazella Maniwavie.

(iv) Sow seeds in an upright position half buried with the emerging leaf or the cracked portion of the seed at ground level. Once the seedlings develop a pair of leaves, they can be handpicked for potting. Cover the seeds with a thin layer of substrate and water daily with brackish or salty water.

(v) For Xylocarpus, germinate the big angular seeds in seed beds or directly in pots. Sow the seeds halfway with the embryo eye just at the substrate surface. Water daily with brackish water.

Figure 14: Cultivating Avicennia Seed
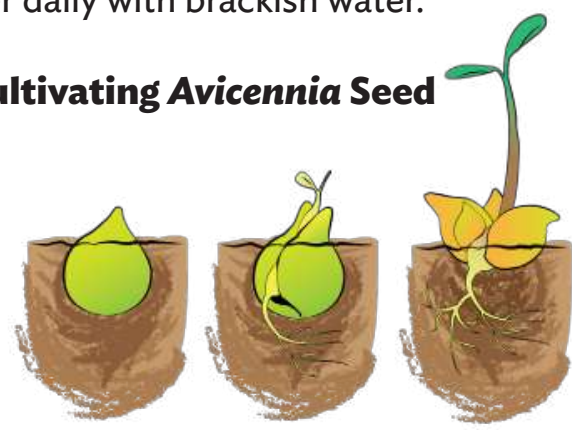

Source: Mazella Maniwavie 
Figure 15: Cultivating Xylocarpus Seed

$\mathbf{c m}=$ centimeter

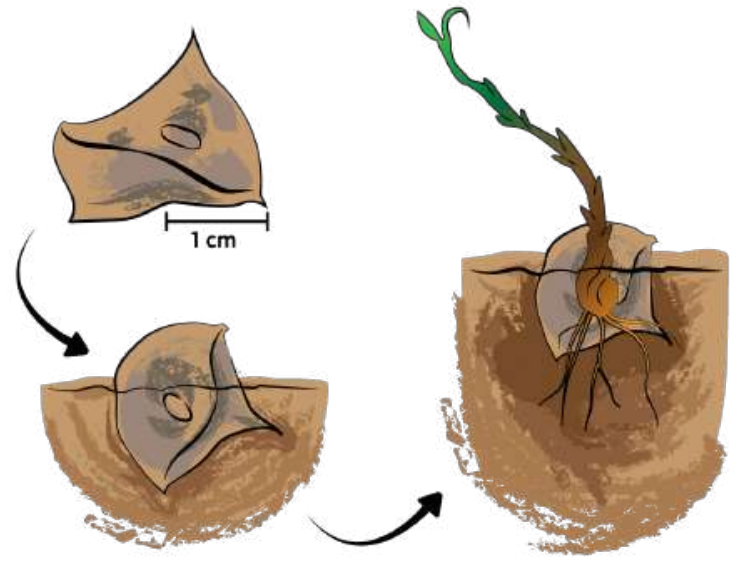

Source: Mazella Maniwavie

\subsubsection{POTTING}

Directly plant propagules and transfer small seedlings from seedbox or seedbed to the polybag before planting in the field.

\subsubsection{SEEDLINGS}

Carefully dig small seedlings out of seedbeds and move them using a flattened stake or spoon to minimize root damage. Plant the seedlings in the bags with the root collar level with the surface of the substrate.

For propagules, place about one-third of their length deep in an appropriately sized bags. For wildings, place them directly into polybags and take extra care not to damage the root system.

Table 9: Examples of Appropriate Polybag Sizes

\begin{tabular}{|c|c|}
\hline Species & $\begin{array}{c}\text { Bag Size } \\
\text { (length } \mathbf{x} \text { width in centimeters) }\end{array}$ \\
\hline Avicennia officinalis & $10 \times 15$ \\
\hline Bruguiera cylindrical & $10 \times 15$ \\
\hline Ceriops tagal & $15 \times 25$ \\
\hline Rhizophora mucronata & $20 \times 30$ \\
\hline Rhizophora stylosa & $15 \times 25$ \\
\hline
\end{tabular}

Source: Simon Wright \& CCDA Technical Working Group. 


\subsection{NURSERY MANAGEMENT}

Useful tools to have at the nursery include a hammer, saw, bush knife, hoe, shovel, small shovel, rake, watering cans or boxes, wheelbarrow, pickmattock, and spading fork.

Organize shifts to operate and manage the nursery on a daily basis. Due to the importance of nursery operations, it is best if community project group (CPG) members assume responsibility for managing the nursery. Typically, it takes 4-6 months to grow out seedlings until they can be transplanted.

The CPG needs to decide the nursery management team and work schedule. It is usually easiest for the management team to consist of several people working part-time to share the work.

\subsubsection{DAILY ACTIVITIES}

Here is a list of daily activities:

(i) Watering. If nursery is located on upland, i.e. at the back of mangroves or not within the intertidal zone, seedlings must be watered twice a day at the early stage with equal amounts of fresh water and saltwater. Later, watering can be done once a day toward the outplanting season (4-6 months old) to acclimatize seedlings. Use fresh water or brackish water before placing seedlings in hardening beds. Water plants as early as possible every morning.

(ii) Shading. Shade the newly potted seedlings from intense sunlight. Shading material usually consists of coconut leaves, nipa palms, or grass for temporary nurseries, while permanent mass production nurseries can use greenhouse shade cloth before the hardening process.

(iii) Weeding. Weed the nursery at least once a week. Weeding is especially necessary when the nursery is located on upland (terrestrial). Remove any plants that are not mangroves and put them in a compost pile.

(iv) Conduct daily inspections for insects and other pests and remove them.

Table 10: Pest and Disease Control Measures

\begin{tabular}{|l|l|l|}
\hline Pest/disease & Damage & Control measures \\
\hline Tussock moth & $\begin{array}{l}\text { Larvae or hairy caterpillar } \\
\text { feeds on leaves of young } \\
\text { seedlings }\end{array}$ & Manual removal of larvae \\
\hline
\end{tabular}

Table 10 continued on next page 


\begin{tabular}{|l|l|l|}
\hline Pest/disease & Damage & Control measures \\
\hline Seed borer & $\begin{array}{l}\text { Bores propagules and } \\
\text { breeds on seedling / } \\
\text { hypocotyl }\end{array}$ & $\begin{array}{l}\text { Removal of propagules with } \\
\text { insect holes } \\
\text { Air-drying of propagules }\end{array}$ \\
\hline Plant lice & $\begin{array}{l}\text { Sucks nutrients of } \\
\text { Rhizophora }\end{array}$ & $\begin{array}{l}\text { Spraying with chemicals or use } \\
\text { chili spray }\end{array}$ \\
\hline Scale insect & $\begin{array}{l}\text { Sucks nutrients causing } \\
\text { curling of leaves }\end{array}$ & $\begin{array}{l}\text { Spraying with chemicals or use } \\
\text { chili spray }\end{array}$ \\
\hline Slug caterpillar & Defoliation (losing leaves) & Manual removal of larvae \\
\hline Bagworm & Defoliation & Manual removal \\
\hline Leaf spot & $\begin{array}{l}\text { Brown spots interfere } \\
\text { with photosynthesis; } \\
\text { defoliation if severe }\end{array}$ & $\begin{array}{l}\text { Removal of infected leaves and } \\
\text { burning }\end{array}$ \\
\hline Rhizophora & $\begin{array}{l}\text { Defoliation; interferes } \\
\text { with photosynthesis }\end{array}$ & $\begin{array}{l}\text { Removal of infected seedlings } \\
\text { and burning mosaic }\end{array}$ \\
\hline
\end{tabular}

Source: Sinohin et al. 1996.

\subsubsection{HARDENING OFF}

The hardening process must take place at least 4 weeks before outplanting. Hardening involves exposing plants to increasing amounts of sunlight until seedlings are fully exposed to sunlight. Also, the amount of watering is reduced. Reduce shade by removing each layer of coconut leaves or nipa palm.

\section{Table 11: A Typical Hardening Process}

\begin{tabular}{|l|l|l|l|l|}
\hline Number of weeks & & & & \\
\hline Treatment & 1 & 2 & 3 & 4 \\
\hline Reduce shading & $\begin{array}{l}\text { Remove first } \\
\text { layer (25\%) }\end{array}$ & $\begin{array}{l}\text { Remove 2nd } \\
\text { layer (50\%) }\end{array}$ & $\begin{array}{l}\text { Remove 3rd } \\
\text { layer (75\%) }\end{array}$ & $\begin{array}{l}\text { No more } \\
\text { shading }\end{array}$ \\
\hline $\begin{array}{l}\text { Reduce watering } \\
\text { frequency }\end{array}$ & Once a day & $\begin{array}{l}\text { Once every } \\
\text { 2 days }\end{array}$ & $\begin{array}{l}\text { Once every } \\
\text { 3 days }\end{array}$ & $\begin{array}{l}\text { No more } \\
\text { watering }\end{array}$ \\
\hline
\end{tabular}

Source: Simon Wright \& CCDA Technical Working Group.

\subsubsection{GRADING, SORTING, AND PACKAGING SEEDLINGS}

After 6 months, select the seedlings that are $50 \mathrm{~cm}$ or more in height. Sort those that meet this minimum requirement before packaging and transport to the planting area. Seedlings that had grown less than $50 \mathrm{~cm}$ should spend more time in the nursery. 


\section{CHAPTER III: PLANTING}

\section{PREPARATION}

The planting sites often need some preparation prior to planting. The community project group should walk over the entire area and determine what needs to be done.

Here are the steps:

(i) Clear the site of unwanted vegetation, debris, plastics, pieces of metal, tree branches, and stumps. Keep in mind the potential for rubbish, such as plastic and other solid wastes brought in by tides, and seasonal accumulations of broken seaweed and seagrass.

(ii) Put up any fencing or barriers that were considered necessary during site assessment in order to prevent damage to seeds, propagules, and seedlings from the threat of pests, debris, livestock, and humans. If needed, construct a simple fence or stone barrier.

(iii) Finally, make sure to estimate how long it will take for the incoming tide to cover the site. This will allow you to work out the amount of labor you will need to complete planting, but most importantly, minimize the loss of seedlings due to drying out.

Mangroves can either be planted directly into the ground on a site or spend time in a nursery before being transplanted.

There are two ways to plant:

(i) Seasonal. Plant your mangroves at the same time that the species would begin to grow naturally. If the species grow year-round, it is best to plant in the wet season. Do not plant during periods of high wind and/or high tides or during cyclone season. Do not plant if flooding occurs. Wait a few days after the flooding before starting to plant.

(ii) Daily. Begin planting during low tide in the front zones of the plantation and move toward the mid and back zones as the tide comes in. 


\section{PLANTING PROPAGULES AND SEEDS}

Here are the guidelines for planting:

(i) Direct planting with propagules or seeds. Mangroves such as Rhizophora, Xylocarpus, and Heritiera littoralis can be planted directly into the substrate in very sheltered sites. If done correctly, this method is cheap and easier than using a nursery, but often fails due to incorrect practices.

(ii) Depending on the species, propagules must be pushed half of their length into the substrate.

(iii) When planting in the ground, place the lower wider half of the propagule into the substrate.

One of the most common reasons for failure using direct planting is that the propagules are pushed too deep into the substrate so that the seeds cannot "breathe" and slowly die.

Figure 16: Correct Planting Depth for Direct Planting of Propagules

Source: Mazella Maniwavie.

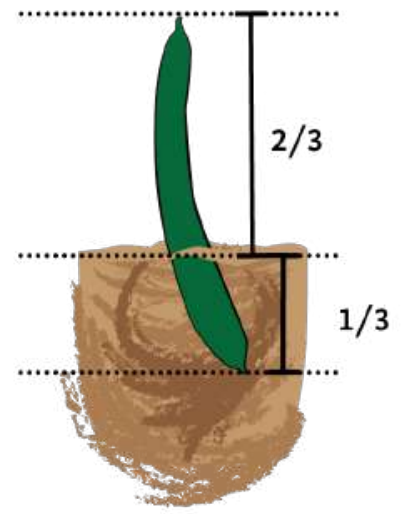

(iv) Avoiding "J" roots. The correct depth for a seedling is when the root collar is in line with the soil and the roots do not touch the sides of the hole (see Figure 17). A tree can die if it is planted too shallow or too deep.

If the roots of the seedling are tangled up or wrapped tightly around the root ball, gently untangle them so that they hang downward. 


\section{Figure 17: Correct Planting Depth}

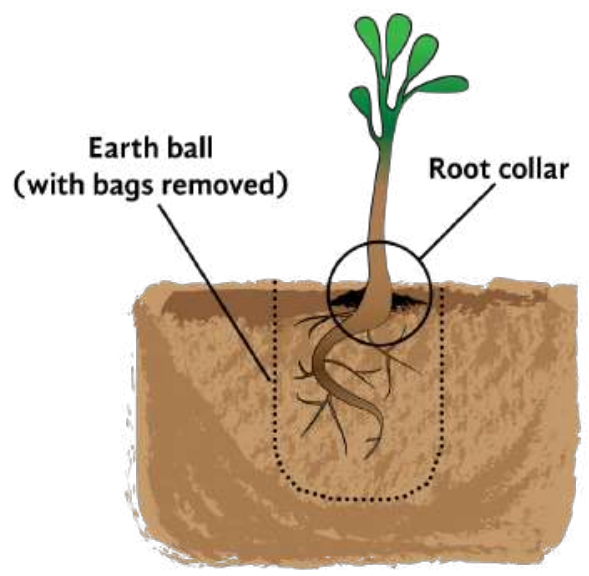

Source: Mazella Maniwavie.

Lower the seedling into the hole until the root collar is in line with the top of the hole, but do not allow the roots of the seedling to touch the hole's sides or bottom. When roots curl upward against the hole (like the letter "J"), it can stunt growth or even kill the plant. You may need two people per seedling to do this.

Have one person fill the hole in with substrate while the other holds the seedling at the same height.

Figure 18: Compacting the Substrate Around a Newly Planted Seedling

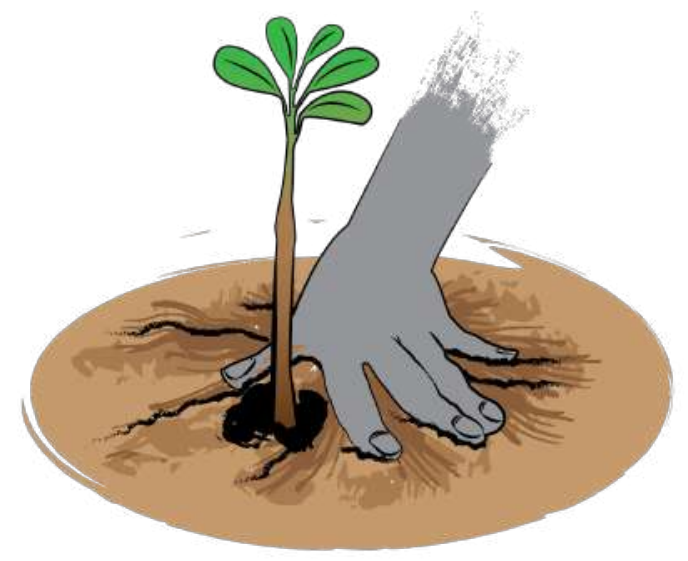

Source: Mazella Maniwavie. 
(v) Loose substrate. Do not trample on the substrate surface after planting a seedling. Lightly fill the substrate into the hole until it is completely filled with loose substrate and gently compact with your hands.

(vi) Spacing. Mangroves do not naturally grow in straight lines, so don't worry about being too exact about spacing when planting your seedlings. Spacing can be from $1 \mathrm{~m}$ to $1.5 \mathrm{~m}$.

(vii) Pruning. If before planting you notice that some roots are damaged, remove them to avoid possible Phytophthora invasion (a disease that destroys the plant roots).

(viii) If the substrate is hard, holes the size of the propagules should be dug before inserting the propagules.

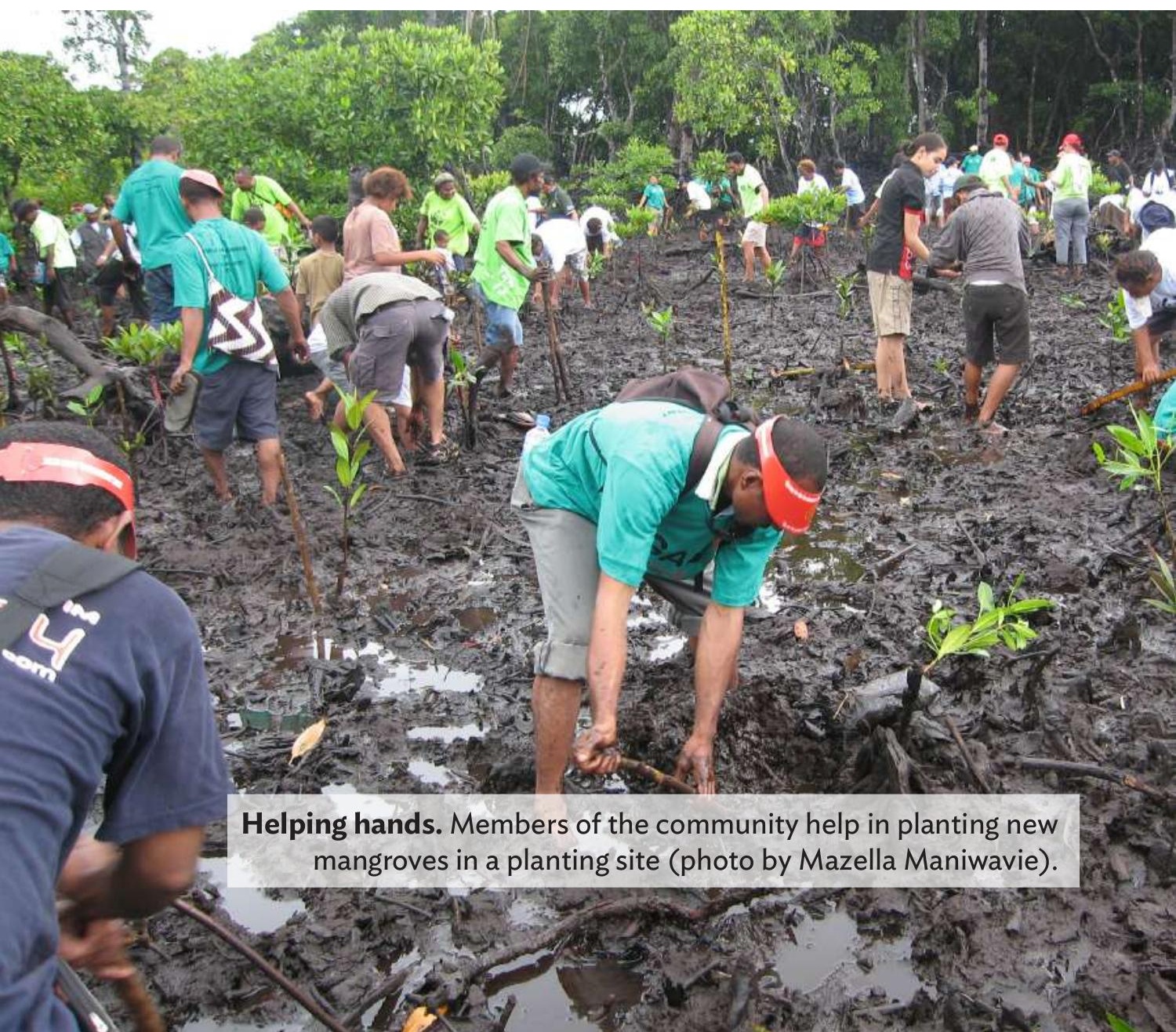




\section{CHAPTER IV: MONITORING}

\section{AND EVALUATION}

The purpose of monitoring is to examine planting activities and collect useful information to improve the project. Many lessons can be learned, including site selection, choice of species, and causes of mortality.

The first 2 years after planting are the most critical and intensive for management, requiring regular monitoring of growing seedlings and maintenance work.

Generally, from the third year onward, the level of care required becomes less, but may involve thinning the trees if they were planted densely and for the purpose of timber production.

\section{TRAINING OF COMMUNITY MEMBERS}

Get an expert to train selected members of your community project group (CPG)on monitoring and evaluation. Techniques learned must support improvement of future activities of the project and replication of the monitoring and evaluation process.

The monitoring techniques used should be in a simplified, standardized form to allow easy, detailed, and accurate measures of progress toward meeting goals or outputs (see Appendix 1, Template 2).

For rehabilitation activities, initial or baseline monitoring and evaluation must contain information on number of seedlings planted, their species, planting techniques, site condition, pests, etc. (see Appendix 1, Template 2). Regular monitoring and evaluation after planting must include data on plant survival rate, threats, replenishment planting, etc.

\subsection{DATA COLLECTION AND STORAGE}

Field data collected must be entered into spreadsheets if you have access to a computer so analyses can be done on the survival rate of seedlings. All field data must be stored in a dedicated and safe place, preferably offsite and must be accessible by all project members.

Experts should continue to be involved in the project as advisors and to monitor aspects of the project which require specialized expertise. 
Table 12: Monitoring Phase Activities

\begin{tabular}{|c|c|}
\hline Activities & Comments \\
\hline $\begin{array}{l}\text { Monitor mangrove species that } \\
\text { develop }\end{array}$ & $\begin{array}{l}\text { Compare success of seedlings according } \\
\text { to species and zones they were planted in } \\
\text { within rehabilitation site. }\end{array}$ \\
\hline $\begin{array}{l}\text { Monitor seedling growth at time } \\
\text { intervals }\end{array}$ & $\begin{array}{l}\text { Measure density (number of seedlings } \\
\text { per } \mathrm{m}^{2} \text { ), percentage cover, and species } \\
\text { composition of both planted mangroves and } \\
\text { those that develop naturally (ask an expert). } \\
\text { Measure average height and the number of } \\
\text { leaves of selected seedlings, and when they } \\
\text { start reproducing (ask an expert) }\end{array}$ \\
\hline Monitor survival rate of plants & $\begin{array}{l}\text { Count the number of seedlings growing and } \\
\text { surviving and workout the survival rate per } \\
\text { year (see Appendixes) }\end{array}$ \\
\hline Record level of failure of saplings & $\begin{array}{l}\text { Provide a scientific explanation for failure } \\
\text { (this may require help from an outside } \\
\text { expert). }\end{array}$ \\
\hline $\begin{array}{l}\text { Record level of rubbish } \\
\text { accumulation }\end{array}$ & $\begin{array}{l}\text { Note source of rubbish and steps taken to } \\
\text { minimize the problem. }\end{array}$ \\
\hline $\begin{array}{l}\text { Adjust spacing of mangrove } \\
\text { seedlings and saplings to an } \\
\text { optimum level }\end{array}$ & $\begin{array}{l}\text { Frequency of thinning (if for timber } \\
\text { production), replanting or natural } \\
\text { regeneration should be noted }\end{array}$ \\
\hline $\begin{array}{l}\text { Estimate cost of restoration } \\
\text { project }\end{array}$ & $\begin{array}{l}\text { The estimation of costs should include all } \\
\text { the undertakings including the preparation, } \\
\text { propagule collection, nursery establishment, } \\
\text { field transplantation, etc. }\end{array}$ \\
\hline $\begin{array}{l}\text { Monitor impact of any harvesting } \\
\text { project }\end{array}$ & $\begin{array}{l}\text { This should be part of any long-term record } \\
\text { for restoration. }\end{array}$ \\
\hline $\begin{array}{l}\text { Monitor characteristics of } \\
\text { the rehabilitated mangrove } \\
\text { ecosystem }\end{array}$ & $\begin{array}{l}\text { This involves detailed measurement of } \\
\text { animals; plants and physical environment } \\
\text { of the new mangrove ecosystem and } \\
\text { comparison with similar undisturbed } \\
\text { mangrove ecosystems (ask an expert). } \\
\\
\text { This is usually done in the third and fifth } \\
\text { year when the plants have matured. }\end{array}$ \\
\hline
\end{tabular}

Source: Field. 1998b. 


\section{MAINTENANCE}

Active maintenance during the early years of the rehabilitation is important to the health and success of the mangroves.

\subsection{MAINTENANCE ACTIVITIES IN THE FIRST 2 YEARS}

Here are maintenance guidelines:

(i) Visit the plantation daily immediately after planting. Remove green algae log floating into the area, before it can do too much damage.

(ii) Once seedlings become established, you can reduce visits to the plantation to few times a week.

(iii) Regularly inspect the entire plantation and specific patches. Imagine the site divided into blocks.

(iv) Look closely at a few plants in each block because it is impossible to look at each and every plant. It is easier to walk around and inspect seedlings across the whole plantation during low tide.

(v) Look out and/or check for encrusting organisms like barnacles and oysters; insects and moth larvae eating leaves; dead or dying plants; and plants entangled in algae, seaweed or seagrass, and plastics.

\subsection{PROTECTING SEEDLINGS}

Here are guidelines to protect seedlings:

(i) Remove encrusting barnacles and oysters. Remove shells by hand before the propagules are totally covered. Do not scrape the propagules with a bush knife since that will result in plant damage and death.

(ii) Remove grazing animals or insects. Pluck them from the leaves, trunks, and branches of the seedlings and place them in a bag. Remove the bag from shore for disposal. Do not throw them in the water because they can reach another tree.

(iii) Remove dead or dying trees. 
(iv) If seedlings are dying in large numbers, it may be necessary to replace them with seedlings from the nursery. Contact an expert to inspect some sample seedlings and determine the cause of mortality, or visit the area to evaluate the site.

(v) Install or repair fences or barriers. If you find extensive problems and it will take more than a few hours to fix, involve more members of the community.

(vi) Remove plastics, pieces of metal, tree branches, and other debris. Keep in mind that debris might come in with tides, as well as seaweeds and seagrass.

\section{Figure 19: Encrusting Barnacles on a Mangrove Sapling}

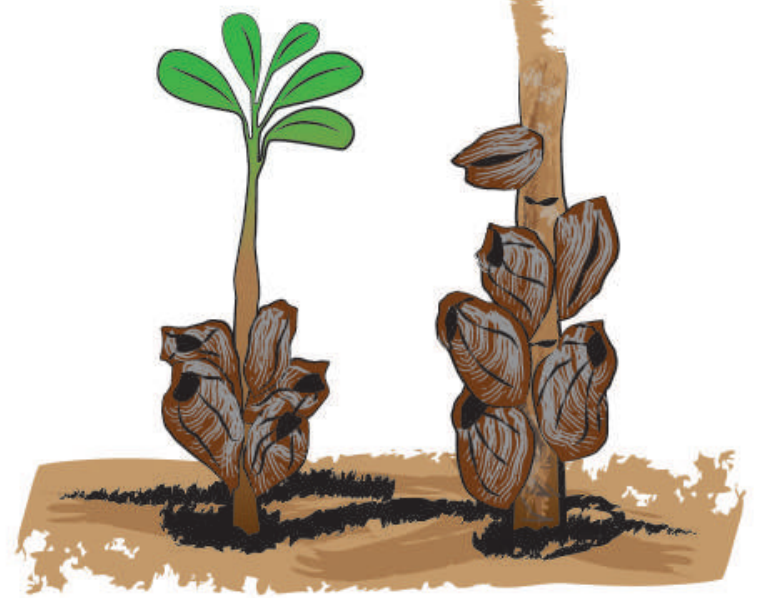

Source: Mazella Maniwavie.

\subsection{CONTINUING MAINTENANCE}

Here are guidelines on continuing maintenance on the site:

(i) Thinning. If you planted mangroves more densely than normal or they have simply all survived and grown very well, it may be necessary to thin them out to allow proper growth for timber purposes. If the trees are below a meter high, it is possible to uproot and move the trees farther apart.

(ii) Pruning. Cut unnecessary branches and stems to enhance height and trunk diameter growth rate. This is recommended for timber production plantations. 
Do not cut more than $30 \%$ of the living branches over a 1- to 2-year period. Over pruning will harm plant growth. For bigger branches, make a cut underneath the branch $10 \mathrm{~cm}$ from the trunk. Then make a cut on the top of the branch close to the trunk to avoid bark splitting.

Both thinning and pruning at the 5 -year point and beyond results in plenty of sustainable fuelwood and construction wood.

\section{PROGRESS REPORTING}

Well-managed projects always have a monitoring, evaluation, and reporting system to keep track of progress. An evaluation is an assessment of the progress of a project over a 1-year period.

These are the key reports that you should produce:

\subsection{PROGRESS REPORT}

This is a basic summary of what activities have been achieved, what is yet to be achieved, and the problems encountered. The progress report should be written yearly and should have a monitoring section which involves an analysis of the status of the nursery and/or planted mangroves. Points to consider include the following:

(i) How many seedlings survived the nursery phase?

(ii) If many seedlings died, what was the cause of mortality?

(iii) How can problems be addressed?

(iv) What stresses are the plant seedling facing? And how can you deal with stresses to increase chances of survival?

\subsection{EVALUATION SECTION}

This part of the report requires more information about the project operations and covers:

(i) How the community responded to the project;

(ii) What the biggest issues were and what was done about them; and

(iii) What the overall attitude of community towards the project. 


\subsection{FINANCIAL REPORT}

Use the budget as your starting point and use records of income and expenditure (such as bank statements or receipts). Summarize actual expenditures and how they compare with the budgeted expenditure.

\subsection{OVERVIEW OF INCOME}

Know how much money came into the project and where it came from. Determine the following:

(i) Donations;

(ii) Government funding (e.g., community budget allocations) or others (e.g., inland support, community time);

(iii) Overview of expenditure and knowing how much money was spent on the project and what it was spent on; and

(iv) The materials and equipment, training costs, activity-related costs, and wages by volunteers.

Have an inventory summary. What equipment and tools did you start with? What did you buy, replace, or lose during the year? What do you have now?

\section{RAISING AWARENESS}

It is important to get as much community support as possible and aim to involve them in all aspects of the project. This will encourage a sense of responsibility that will improve the chances of long-term survival of the mangroves.

Organize a community gathering or use an existing forum like a church open session. Ask the Climate Change and Development Authority and nongovernment organizations (NGOs) for awareness material such as posters, brochures, and presentations to help explain climate change and the benefits that mangroves bring. 
Repeat awareness activities to maintain support and involvement of the community and meet with community leaders. Also meet with families and fishers living near your site or bordering healthy mangroves areas. Have the community select a community project manager (CPM) and form the CPG.

Involve the community in all aspects of the project and have them take ownership and drive the project. This will encourage a sense of responsibility for the mangrove community and help with the sometimes labor-intensive work.

\section{TRAINING}

It is important that the CPM has the required skills and knowledge to lead the project. Such skills will also need to be passed on from the CPM to the rest of the CPG as well as temporary volunteers.

The CPM should have skills in mangrove rehabilitation and management, project management, financial management, alternative livelihoods, and reporting.

To further improve the abilities of the project team, attend mangrove training workshops organized by the government or NGOs.

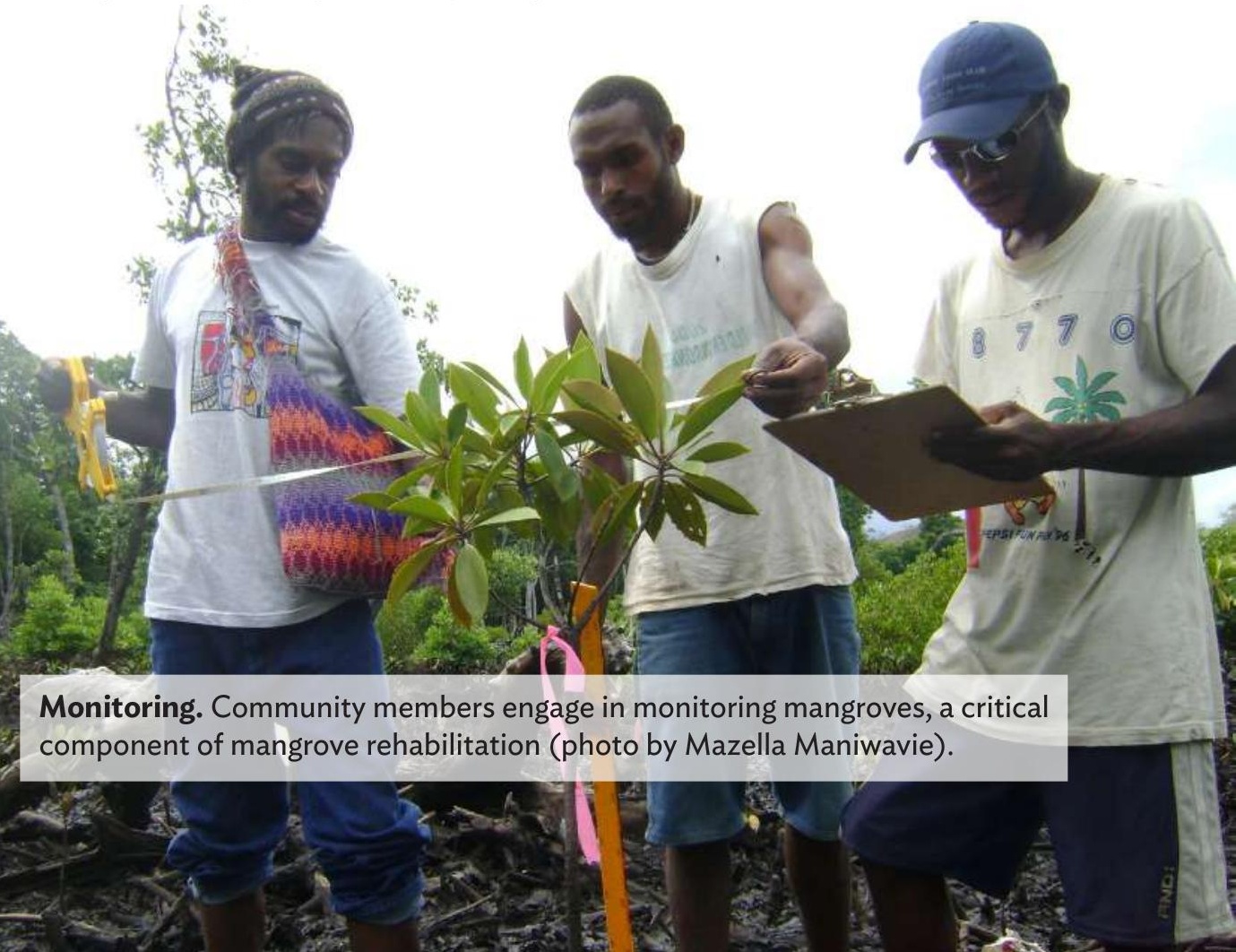




\section{CHAPTER V: PROJECT FUNDING}

\section{PROJECT COSTING}

Before you can ask for funding, estimate what you will need and how much the requirements cost. When asking for funding, donors will almost always want to see a budget of the project.

Here are the guidelines:

(i) Develop your budget. Prepare your budget at the same time as you develop your basic workplan.

(ii) Estimate costs. Costs to think about are building materials, equipment, wages, incentives (such as food for labor), transportation, and other costs (e.g., fund-raising costs of an event to raise money for the project). Avoid paying incentives as people may expect or even demand compensation.

(iii) Estimate income. Think about how you will fund your project. Can you conduct the activity without money and use only in-kind contributions and available resources? Will you get money from the community? Will you receive government funding? Can you find a company to sponsor it?

(iv) Identify sources of funding. If you are fund-raising, estimate how much you think people are willing to give, but be careful not to overestimate.

(v) Refine your budget. Once you have identified the necessary changes, incorporate them into your budget.

\section{IDENTIFYING FUNDING SOURCES}

Additional financial support may be necessary under certain circumstances. Below are some of the different funding sources that may be available, as well as their respective advantages and disadvantages.

(i) National. One of the advantages is that several agencies are focused on disaster risk reduction, climate change, and the environment. However, the funds are usually not provided directly to communities. 
(ii) Provincial and district government. One advantage is that local governments can provide direct support. However, one disadvantage is that there might be few or no funds focused on disaster risk reduction. The funds can also be quite small.

(iii) Development agencies. Many agencies have access to large funds and a mandate to support either disaster risk reduction, climate change, and environmental cause. However, they sometimes do not provide direct support for communities and they can be selective on who to support.

(iv) Nongovernment organizations. There are many NGOs supporting disaster risk reduction projects. However, many NGOs do not provide direct financial support to communities.

(v) Private sector. Many firms are looking to support environment projects and most can move fast once a project is identified. However, it is unclear how

much funding is available and it is unclear how many organizations are willing to give support.

(vi) Community-raised funds. Many community members are willing to contribute funds. However, not all community members will be interested in a specific project.

\section{APPLYING FOR AND SECURING FUNDS}

Applying for funds can be challenging. Below are five things that almost any donor would want you to provide:

(i) A project summary of the purpose, goals and activities, including personnel and stakeholders, dates, and locations;

(ii) An overall project work plan (Chapter I);

(iii) A budget with justification for line items;

(iv) The community's contribution to the project (cash contributions or in kind, such as volunteer time); and

(v) A financial management summary of how you plan to manage the funds (e.g., bank account, trust fund, signatories). 


\section{TARGETING APPROPRIATE FUNDING SOURCES}

After determining your funding needs, you can now look for sources. Below are some things to look for:

(i) Alignment. Are the goals of your project in line with the goals of the fund? The application process should be straightforward.

(ii) Geographic coverage. Does the fund support projects in your province/district/LLG/ward? If a fund is limited by mandate to a particular area, it is unlikely to be able to support your project.

Some funds are not limited to areas but still prefer to support only projects in areas that they are already active in.

(iii) Conditions and limitations. What kind of conditions does the fund apply to for its support? Are there performance requirements? Are there specific things the fund does not support (e.g., livelihood activities, salaries)?

(iv) Size. How much funding do they have available? What is the maximum amount of funding they can provide? It is normally easier to receive funding from many small funds rather than a few large ones, but they can be harder to manage.

(v) Time horizon. How long (months, years, etc.) is the support? Try to secure funding over several years to increase the long-term sustainability of your project.

(vi) Track record. Has the fund already supported similar projects? If the fund has supported similar projects, it often means the fund will be more likely to fund your project.

(vii) Turnaround. How quickly does the fund move from applications to providing support? 


\section{GLOSSARY}

Abiotic - Refers to the nonliving components of the environment e.g. water and soil.

Abscission collar - The part joining the cap of a propagule to the hypocotyl, where the hypocotyl when ripe detaches from

Anaerobic - Lacking oxygen

Biodiversity - The number and relative abundance of different species of plants, animals and microorganisms, in an ecosystem

Biomass - Total weight of animals and /or plants per unit area

Ecosystem - A unit made up of the complex interactions of the biotic community of plants, animals and microorganisms, including humans with the abiotic environment such as soil, water and temperature

Family - A group consisting of related genera of plants or animals that share similar characteristics. E.g. Rhizophoraceae

Hypocotyl - The portion of a seedling between the stem and root. In rhizophora, it is the main cylindrical part of the propagule

Intertidal zone - Generally refers to the area that is above water at low tide and under water at high tide

Inundation - A condition in which water from any source temporarily or permanently covers a land surface

Mangrove - Trees, shrubs, palms or ground ferns growing in the zone between high and low tide marks

Nursery bed - A bed used to grow seedlings until they are ready to be planted in a permanent site

Propagules - Any seed, fruit or other part of a plant which when dispersed is able to produce a new plant. Here we refer to the viviparous fruits or seeds of the Rhizophoraceae family.

Zonation - Arrangement or distribution in zones.

Zones - These are groupings of the same species of mangroves within a whole mangrove forest; a belt or area to which certain species are limited 


\section{REFERENCES}

O. Bovell. 2011. Guyana Mangrove Nursery Manual. Guyana Mangrove Restoration Project. 23 pp.

B. Brown. 2004. Do Your Own Mangrove Action Project: An Action-Research Problem-Solving Method. Mangrove Action Project, Yogyakata, Indonesia.

H.T. Chan and S. Baba. 2009. Manual on Guidelines for Rehabilitation of Coastal Forests damaged by Natural Hazards in the Asia-Pacific Region. International Society for Mangrove Ecosystems (ISME) and International Tropical Timber Organization (ITTO), 66 pp.

N.C. Duke. 2006. Australia's Mangroves: The Authoritative Guide to Australia's Mangrove Plants. University of Queensland, Brisbane, $200 \mathrm{pp}$.

I.C. Feller and M. Sitnik. 1996. Mangrove ecology: a manual for a field course. Smithsonian Institution, Washington, DC, $21 \mathrm{pp}$.

C.D. Field. 1996. Restoration for Mangrove Ecosystems. International Society for Mangrove Ecosystems, Okinawa, Japan.

U. Gattenlöhner, S. Lampert, and K. Wunderlich. 2007. Mangrove Rehabilitation Guidebook.Global Nature Fund. Radolfzell, Germany, 68 pp.

S. Giesen. et. al. 2007. Mangrove Guidebook for Southeast Asia. FAO Regional Office for Asia and the Pacific.

E. Gilman et. al. 2006. Pacific Island Mangroves in a Changing Climate and Rising Sea. UNEP Regional Seas Reports and Studies No. 179. United Nations Environment Programme, Regional Seas Programme, Nairobi, Kenya.

Government of the Philippines, Department of Environment and Natural Resources (DENR), Ecosystems Research and Development Bureau (ERDB). [Year.] Guidelines for Community-Based Rehabilitation of Mangroves. DENR Recommends Vol. 5.

T. Hiraishi. and K. Harada. 2003. Greenbelt tsunami prevention in SouthPacific region. Report of the Port and Airport Research Institute, 42(2), 1-23. 


\section{REFERENCES}

J.G. Kairo. 2008. Conservation and management of mangrove forests in Kenya. Mangrove Reforestation Program Kenya Marine and Fisheries Research Institute. Mombasa, Kenya.

S. Kitamura, et. al. 1997. Handbook of Mangroves in Indonesia -Bali and Lombok. International Society for Mangrove Ecosystems (ISME). Tokyo, Japan.

R. Lewis III, B. Streever, and R.F. Theriot. 2000. Restoration of mangrove habitat. Engineer Research and Development Center, Vicksburg MS Environmental Lab.

K.A. Longman. 2003. Raising seedlings of tropical trees (Vol. 2).

Commonwealth Secretariat. London, United Kingdom, 156 pp.

C. C Lovelock. 1993. Field Guide to the Mangroves of Queensland. Australian Institute of Marine Science (AIMS).

M.Maniwavie. 2013. Survival Rates and Factors Controlling the Survivorship of Mangrove Seedlings at Selected Replanted Sites in Central Province, Papua New Guinea. Biology Department. Port Moresby, University of Papua New Guinea.

T.Maniwavie. 2009. An Introductory Manual on the Biology and Restoration of Mangrove Ecosystems. Motupore Island Research Centre Educational and Outreach Programme..

S. Maniwavie. 2007. A Pictorial guide to the Mangroves of Papua New Guinea.

T. J. Marquardt and M. Trevena. 2009. Protecting Mangroves: Benefits for People and the Environment, Reforestation Efforts and Experience from San Agustin. An Education Kit. Center for Education, Research and Volunteerism (CERV) in the Philippines and Meaningful Volunteer, Philippines, $84 \mathrm{pp}$.

McLeod and R.V. Salm. 2006. Managing Mangroves for Resilience to Climate Change. IUCN, Gland, Switzerland, 64 pp. 


\section{REFERENCES}

D.M. Melana. et. al. 2000. Mangrove Management Handbook.

Department of Environment and Natural Resources, Manila, Philippines through the Coastal Resource Management Project, Cebu City, Philippines, $96 \mathrm{pp}$.

Percival and J.S. Womersley. 1975. Floristics and Ecology of the Mangrove Vegetation of Papua New Guinea. Botany Bull No.8. Department of Forests Papua New Guinea, 96 pp.

J.H Primavera and J.M. A. Esteban. 2008. A review of mangrove rehabilitation in the Philippines: successes, failures and future prospects. Wetlands Ecology and Management. 16(5), 345-358.

Ramasubramanian and R. Ravishankar. 2004. Manual on Mangrove Nursery Raising Techniques. M.S. Swaminathan Research Foundation, Chennai, India, 48 pp.

Rasool and S.M. Saifullah. 2005. A new technique for growing the grey mangrove Avicennia marina (Forssk.) Vierh., in the field. Pakistan Journal of Botany. 37, 969-972.

M.N. Raga. 2006. Water use survey report, Barakau village, Central Province, Papua New Guinea. SPREP. Apia, Samoa.

Salmo, D, Torio, and J.M. Esteban. 2007. Evaluation of rehabilitation strategies and management schemes for the improvement of mangrove management programs in Lingayen Gulf. Science Diliman, 19(1).

Sheaves. 2009. Preliminary Evaluation of Mullins Harbour Coastal Wetland Complex: Habitat Inventory, Condition and Threats. A report to Conservation International, Port Moresby.

Spalding, M. Kainuma, and L. Collins, L. 2010. World Atlas of Mangroves. Earthscan. M. M.Stewart and S. Fairfull. 2008. Mangroves. In Industries, NDOP (Ed.). Sydney, NSW Government.

I.N.N. Suryadiputra and K. Telly. 2007. Demonstration of Communitybased Mangrove Reforestation in Aquaculture Landscapes to Promote Ecological Productivity, Sustainability and Environmental Security in Aceh, Indonesia. Wetlands International - Indonesia Programme, Bogor. 

APPENDIXES 


\section{APPENDIX 1}

TABLE A1.1a: Basic Budget Template - Income

\begin{tabular}{|l|l|l|l|l|}
\hline \multirow{4}{*}{ Category } & $\begin{array}{c}\text { Description } \\
\text { (e.g.Church } \\
\text { fundraiser) }\end{array}$ & $\begin{array}{c}\text { Budget } \\
\text { amount }\end{array}$ & $\begin{array}{c}\text { Actual } \\
\text { amount }\end{array}$ & Difference \\
\hline Income & & & & \\
\hline \multirow{4}{*}{$\begin{array}{l}\text { Community } \\
\text { fund-raising }\end{array}$} & & & & \\
\cline { 2 - 5 } & & & & \\
\cline { 2 - 5 } & & & & \\
\hline Subtotal & & & & \\
\hline Government \\
funding
\end{tabular}

Note: For each category item, there should be supporting information and calculations that show how you arrived at the numbers in the basic budget 
TABLE A2: Basic Budget Template - Expenses

\begin{tabular}{|c|c|c|c|c|}
\hline Category & $\begin{array}{l}\text { Description } \\
\text { (e.g.Church } \\
\text { fund-raiser) }\end{array}$ & $\begin{array}{l}\text { Budget } \\
\text { amount }\end{array}$ & $\begin{array}{c}\text { Actual } \\
\text { amount }\end{array}$ & Difference \\
\hline \multicolumn{5}{|l|}{ Expenses } \\
\hline \multirow{2}{*}{\multicolumn{5}{|c|}{$\begin{array}{l}\text { Community } \\
\text { fund-raising }\end{array}$}} \\
\hline & & & & \\
\hline & & & & \\
\hline & & & & \\
\hline \multicolumn{5}{|l|}{ Subtotal } \\
\hline \multirow{2}{*}{\multicolumn{5}{|c|}{$\begin{array}{l}\text { Government } \\
\text { funding }\end{array}$}} \\
\hline & & & & \\
\hline & & & & \\
\hline & & & & \\
\hline \multicolumn{5}{|l|}{ Subtotal } \\
\hline \multicolumn{5}{|l|}{ Donor funding } \\
\hline & & & & \\
\hline & & & & \\
\hline & & & & \\
\hline \multicolumn{5}{|l|}{ Subtotal } \\
\hline \multicolumn{5}{|l|}{ Other } \\
\hline & & & & \\
\hline & & & & \\
\hline \multicolumn{5}{|l|}{ Subtotal } \\
\hline \multicolumn{5}{|l|}{ Total } \\
\hline & & & & \\
\hline
\end{tabular}




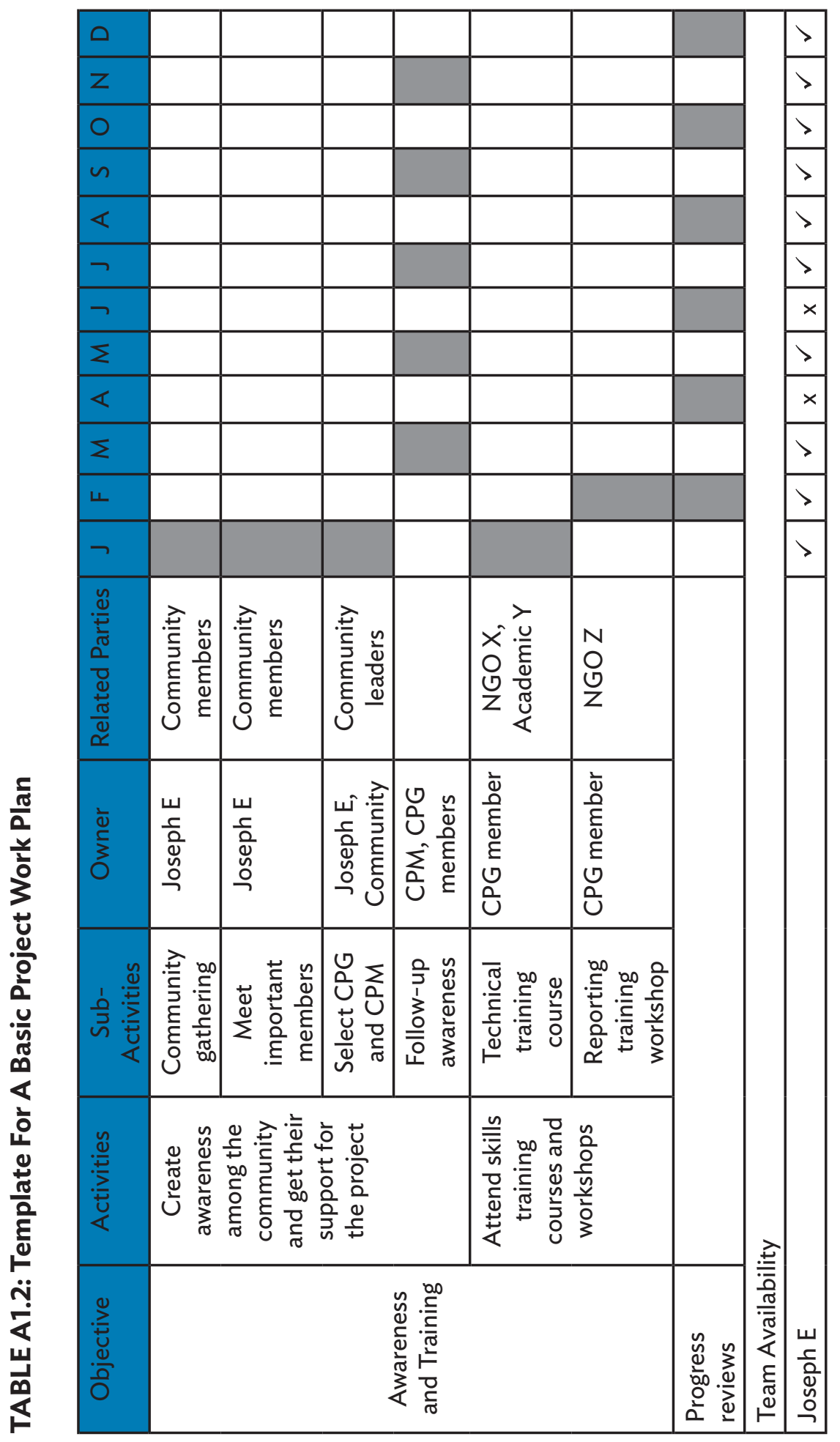




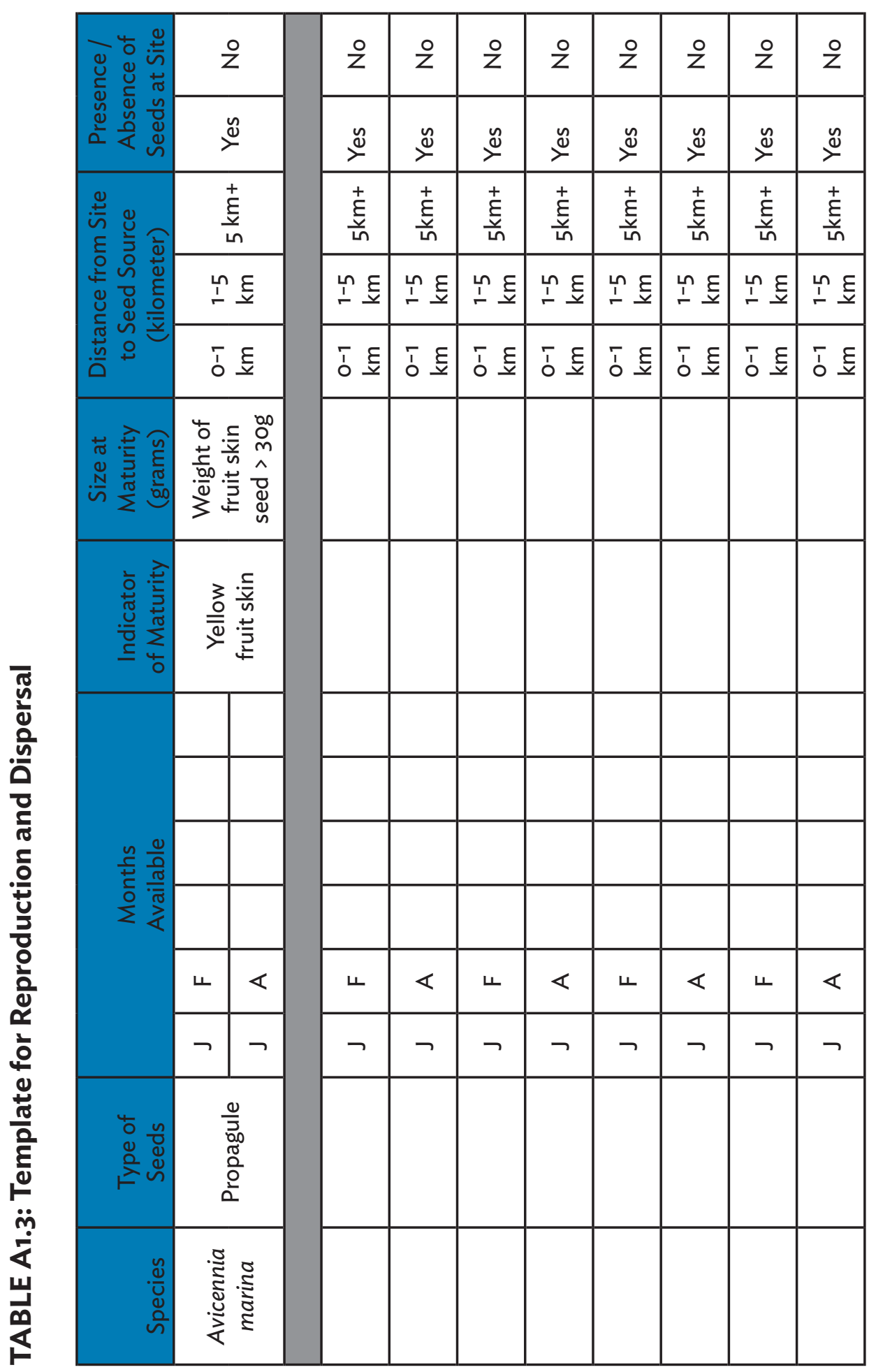


TABLE A1.4: Planting Zones of Different Mangrove Species

\begin{tabular}{|c|c|c|c|}
\hline Name of Species & $\begin{array}{l}\text { ID } \\
\text { Code }\end{array}$ & $\begin{array}{l}\text { Noticeable } \\
\text { Characteristics }\end{array}$ & $\begin{array}{l}\text { Sites and Zones that are Best } \\
\text { for Growth }\end{array}$ \\
\hline Aegialitis annulata & $\mathrm{Aa}$ & Club mangrove & Seafront gravelly substrate \\
\hline $\begin{array}{l}\text { Aegiceras } \\
\text { corniculatum }\end{array}$ & $\overline{A c}$ & Chilli fruit & $\begin{array}{l}\text { Muddy/silt/clay and } \\
\text { loam- tidal creeks }\end{array}$ \\
\hline Avicenna alba & $\mathrm{Aa}$ & $\begin{array}{l}\text { Pronounced } \\
\text { beak fruit }\end{array}$ & Mangrove back/ silty clay \\
\hline Avicenna lanata & $\mathrm{Al}$ & Beak hairy fruit & $\begin{array}{l}\text { Muddy/silt/clay /loam-tidal } \\
\text { creeks /back }\end{array}$ \\
\hline Avicenna marina & $\mathrm{Am}$ & White mangrove & $\begin{array}{l}\text { Any zone and sites tolerant to } \\
\text { high salt }\end{array}$ \\
\hline Avicenna officinalis & Ao & Hairy seeds & $\begin{array}{l}\text { Muddy/silt/clay at back of } \\
\text { mangroves }\end{array}$ \\
\hline $\begin{array}{l}\text { Bruguiera } \\
\text { gymnorrhiza }\end{array}$ & $\mathrm{Bg}$ & Red flowers & $\begin{array}{l}\text { Muddy/silt/clay - with and } \\
\text { back of R. stylosa }\end{array}$ \\
\hline Bruguiera cylindrical & $\mathrm{Bc}$ & Reflexed in fruit & $\begin{array}{l}\text { Muddy/silt/clay/loam- back/ } \\
\text { along tidal creeks }\end{array}$ \\
\hline Bruguiera exaristata & $\mathrm{Be}$ & Yellowish flower & $\begin{array}{l}\text { Mangrove back, near salt } \\
\text { marches }\end{array}$ \\
\hline Bruguiera parviflora & $\mathrm{Bp}$ & $\begin{array}{l}\text { Yellowish flower, } \\
\text { erect in fruit }\end{array}$ & Middle of mangrove \\
\hline Bruguiera sexangula & Bs & Yellowish flower & $\begin{array}{l}\text { Along tidal creeks, muddy, silt, } \\
\text { and clay }\end{array}$ \\
\hline Ceriops australis & $\mathrm{Ca}$ & $\begin{array}{l}\text { Smooth surface } \\
\text { fruit }\end{array}$ & $\begin{array}{l}\text { Mangrove back/tidal creeks- } \\
\text { muddy/silt/clay }\end{array}$ \\
\hline Ceriops decandra & $\mathrm{Cd}$ & upright fruit & $\begin{array}{l}\text { Mangrove back/tidal creeks- } \\
\text { muddy/silt/clay }\end{array}$ \\
\hline Ceriops tagal & $\mathrm{Ct}$ & Ridged fruit & $\begin{array}{l}\text { Mangrove back/tidal creeks- } \\
\text { muddy/silt/clay }\end{array}$ \\
\hline Excoecaria agallocha & $\mathrm{Ea}$ & White sap & Sandy/rocky/clay soils - back \\
\hline Heritiera littoralis & $\mathrm{HI}$ & $\begin{array}{l}\text { leaf underside } \\
\text { silvery }\end{array}$ & $\begin{array}{l}\text { Mangrove back, hard clay - } \\
\text { back }\end{array}$ \\
\hline Lumnitzera racemosa & $\mathrm{Lr}$ & $\begin{array}{l}\text { Succulent } \\
\text { leaves, white } \\
\text { petals }\end{array}$ & $\begin{array}{l}\text { Mangrove back - sandy clays } \\
\text { - back }\end{array}$ \\
\hline
\end{tabular}


Table A1.4 continued

\begin{tabular}{|c|c|c|c|}
\hline Name of Species & $\begin{array}{l}\text { ID } \\
\text { Code }\end{array}$ & $\begin{array}{c}\text { Noticeable } \\
\text { Characteristics }\end{array}$ & $\begin{array}{l}\text { Sites and Zones that are Best } \\
\text { for Growth }\end{array}$ \\
\hline Lumnitzera littoralis & LI & $\begin{array}{l}\text { Succulent } \\
\text { leaves, red petals }\end{array}$ & $\begin{array}{l}\text { Mangrove back - sandy clays } \\
\text { - back }\end{array}$ \\
\hline Nypa fruticans & $\mathrm{Nf}$ & Wild sago & $\begin{array}{l}\text { Plenty of freshwater - } \\
\text { entrance/creeks/rivers }\end{array}$ \\
\hline Osbornia octodonta & Oo & Smelly leaf & $\begin{array}{l}\text { Sandy/gravely/rocky both } \\
\text { seafront/back }\end{array}$ \\
\hline Pemphis acidula & $\mathrm{Pa}$ & $\begin{array}{l}\text { Tiny capsule } \\
\text { fruit }\end{array}$ & $\begin{array}{l}\text { Only on rocky shores with high } \\
\text { salinity }\end{array}$ \\
\hline Rhizophora apiculata & $\mathrm{Ra}$ & $\begin{array}{l}\text { Question mark } \\
\text { shaped fruit }\end{array}$ & $\begin{array}{l}\text { Muddy silt and clay at the } \\
\text { back of } R \text {. stylosa }\end{array}$ \\
\hline $\begin{array}{l}\text { Rhizophora } \\
\text { mucronata }\end{array}$ & $\mathrm{Rm}$ & $\begin{array}{l}\text { Leaves and fruits } \\
\text { larger than } \mathrm{Ra} \\
\text { and } \mathrm{Rs}\end{array}$ & $\begin{array}{l}\text { Muddy silt/clay along tidal } \\
\text { creeks and Bays }\end{array}$ \\
\hline Rhizophora stylosa & Rs & $\begin{array}{l}\text { Well developed } \\
\text { stilt roots }\end{array}$ & $\begin{array}{l}\text { Rocky/clay/silt/sandy/gravely/ } \\
\text { sea front }\end{array}$ \\
\hline $\begin{array}{c}\text { Scyphiphora } \\
\text { hydrophyllacea }\end{array}$ & Sh & Gear fruit & $\begin{array}{l}\text { Loam, less mud and silt, inner } \\
\text { riverbanks }\end{array}$ \\
\hline Sonneratia alba & $\mathrm{Sa}$ & $\begin{array}{l}\text { Star fruit, calyx } \\
\text { reflexed }\end{array}$ & $\begin{array}{l}\text { Mud mixed with gravel, best at } \\
\text { river mouths }\end{array}$ \\
\hline Sonneratia caseolaris & Sc & $\begin{array}{l}\text { Start fruit red } \\
\text { flowers }\end{array}$ & $\begin{array}{l}\text { Muddy, areas of high rainfall } \\
\text { year-round }\end{array}$ \\
\hline Xylocarpus granatum & $\mathrm{Xg}$ & $\begin{array}{l}\text { Cannonball } \\
\text { mangrove/brown } \\
\text { fruit }\end{array}$ & $\begin{array}{l}\text { Muddy silt and clay along tidal } \\
\text { creeks }\end{array}$ \\
\hline $\begin{array}{l}\text { Xylocarpus } \\
\text { moluccensis }\end{array}$ & $\mathrm{Xa}$ & $\begin{array}{l}\text { Green guava } \\
\text { fruit }\end{array}$ & $\begin{array}{l}\text { Muddy silt and clay along tidal } \\
\text { creeks }\end{array}$ \\
\hline Xylocarpus rumphii & $\mathrm{Xr}$ & Small guava fruit & $\begin{array}{l}\text { Rocky sandy shores with wave } \\
\text { exposure }\end{array}$ \\
\hline
\end{tabular}


TABLE A1.5: Seed Collection Indicators of Ripe Seeds or Propagules for Various Mangrove Species

\begin{tabular}{|l|c|l|}
\hline \multicolumn{1}{|c|}{ Mangrove species } & $\begin{array}{c}\text { Seeds (s) or } \\
\text { Propagules (p) }\end{array}$ & \multicolumn{1}{|c|}{ Condition for collection } \\
\hline Aegiceras corniculatum & $\mathrm{p}$ & $\begin{array}{l}\text { Fruits become lightly pinkish } \\
\text { to brown. }\end{array}$ \\
\hline Avicennia spp. & $\mathrm{s}$ & $\begin{array}{l}\text { Seeds coat changes from green } \\
\text { to light yellow. Seed coat becomes } \\
\text { wrinkly. }\end{array}$ \\
\hline Bruguiera spp. & $\mathrm{p}$ & $\begin{array}{l}\text { No abscission collar. The hypocotyl } \\
\text { changes color from green to brown. }\end{array}$ \\
\hline Ceriops spp. & $\mathrm{p}$ & $\begin{array}{l}\text { Yellow abscission collar. The } \\
\text { hypocotyl sometimes changes from } \\
\text { green to red brown. }\end{array}$ \\
\hline Heritiera littorea & $\mathrm{s}$ & Mature fruit is dark brown. \\
\hline Nypa fruticans & $\mathrm{s}$ & $\begin{array}{l}\text { Seeds change from light brown to } \\
\text { dark brown. }\end{array}$ \\
\hline Rhizophora apiculata & $\mathrm{p}$ & Reddish abscission collar \\
\hline Rhizophora mucronata & $\mathrm{p}$ & Yellow abscission collar \\
\hline Rhizophora stylosa & $\mathrm{p}$ & Yellow abscission collar \\
\hline Sonneratia spp. & $\mathrm{s}$ & $\begin{array}{l}\text { Fruit changes colour from pale green } \\
\text { to dark green with maturation. }\end{array}$ \\
\hline Xylocarpus granatum & $\mathrm{s}$ & $\begin{array}{l}\text { Fruit changes colour from light green } \\
\text { to dark. }\end{array}$ \\
\hline $\begin{array}{l}\text { Xylocarpus moluc- } \\
\text { censis }\end{array}$ & $\mathrm{s}$ & $\begin{array}{l}\text { Yellow to brown fruit and floats in } \\
\text { water. }\end{array}$ \\
\hline
\end{tabular}

Source: C. C. Field. 1996. 
TEMPLATE 1: Examples of Propagules and Seeds

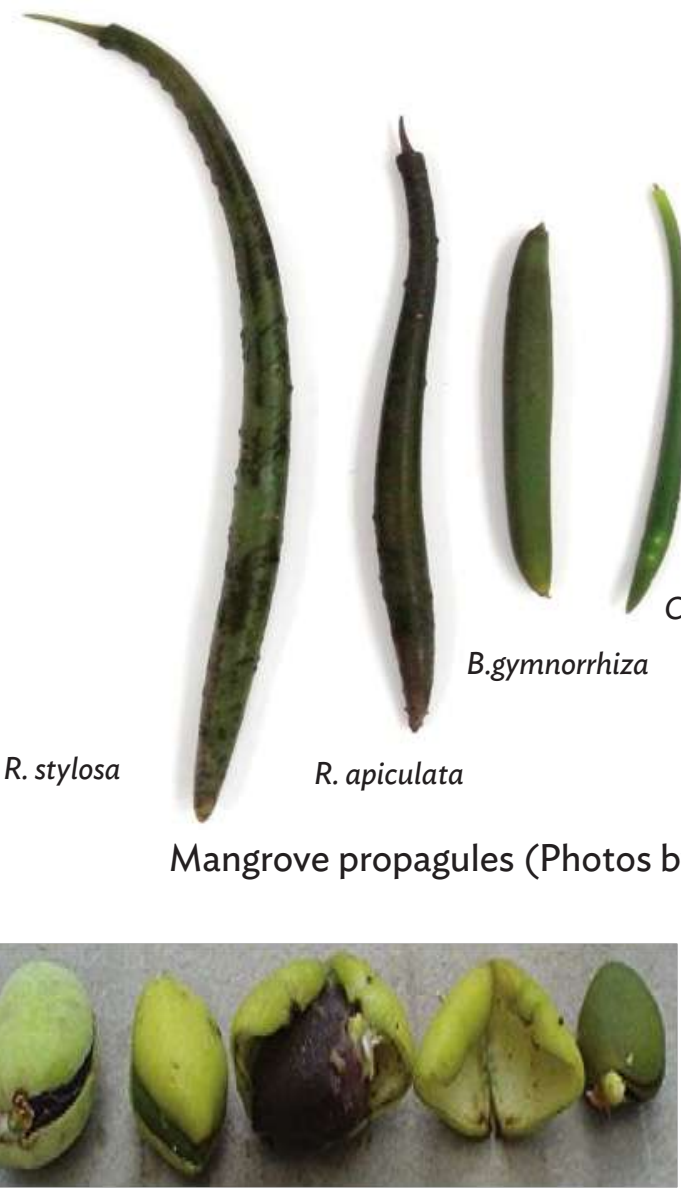

Mature seeds of $A$. marina

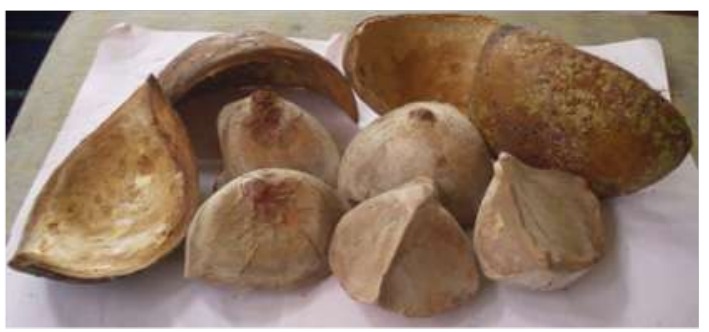

Mature seeds of X. granatum

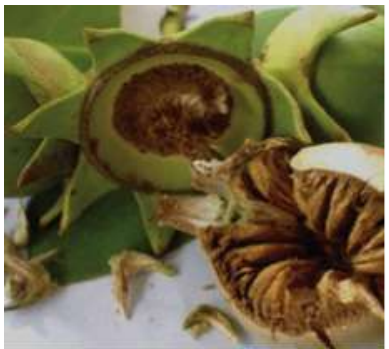

Mature fruit of S. alba containing seeds

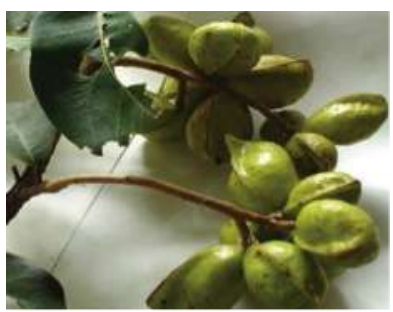

Seeds of $H$. littorea

Mangrove seeds (Photos by Thomas Maniwavie) 


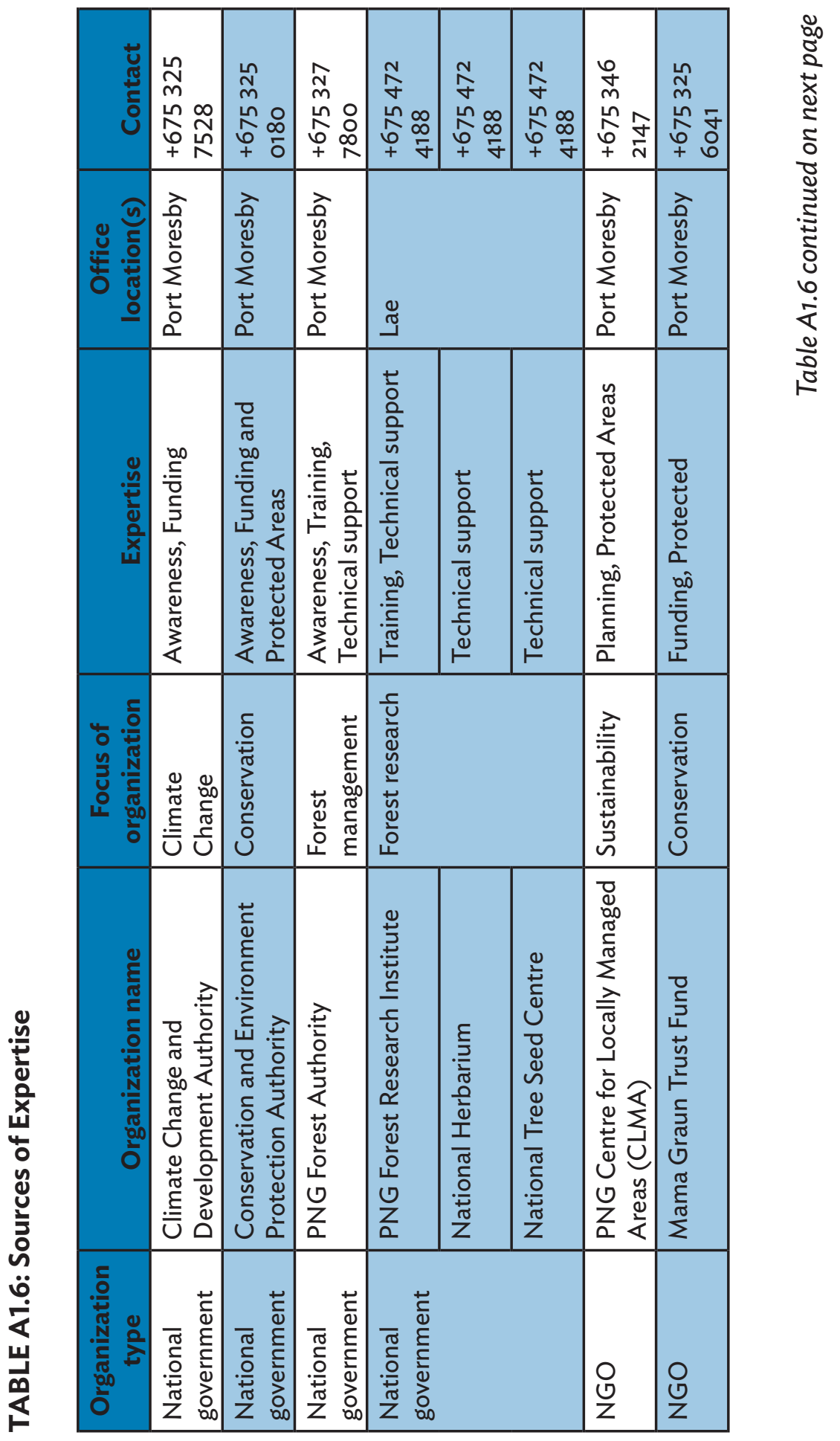




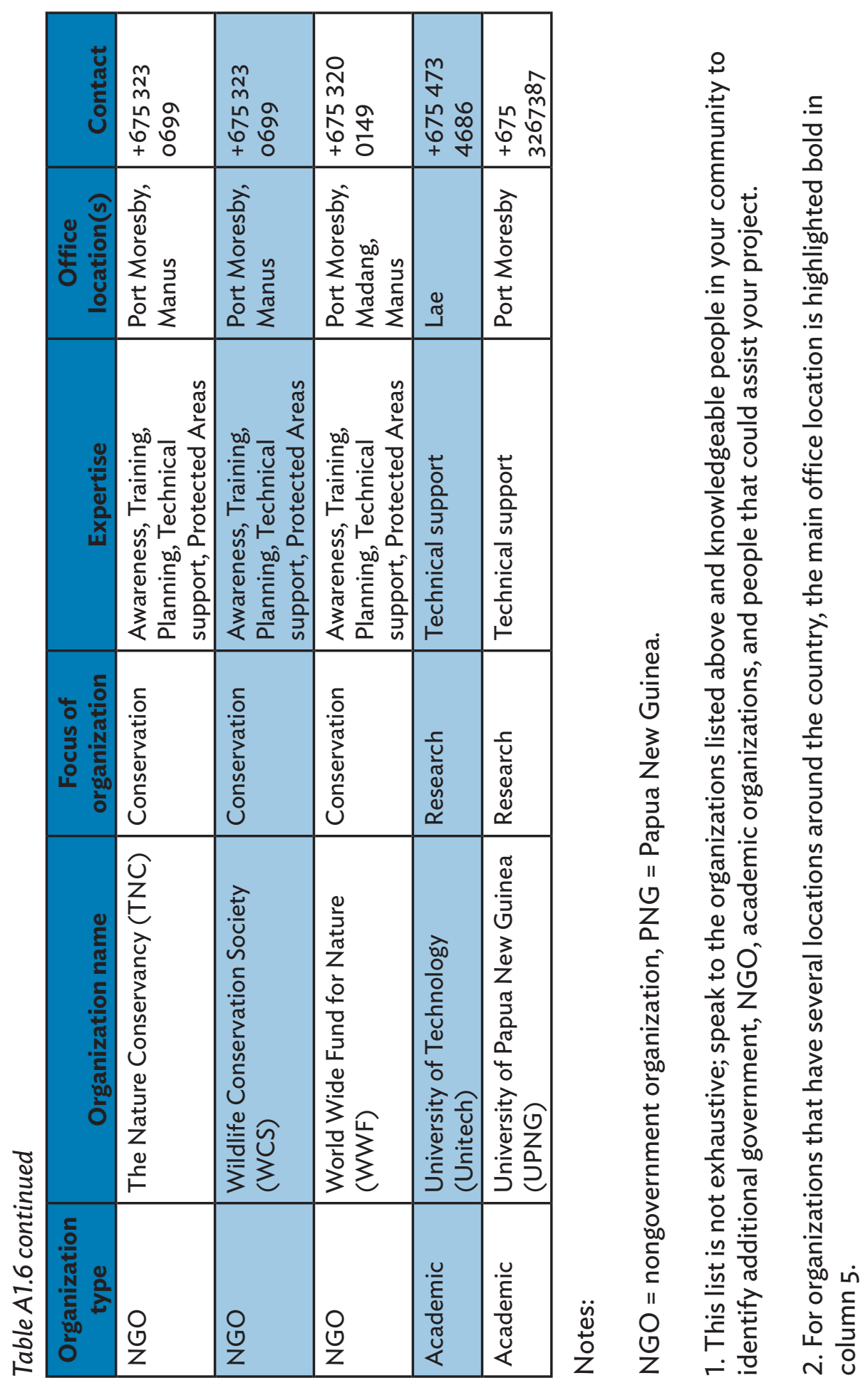




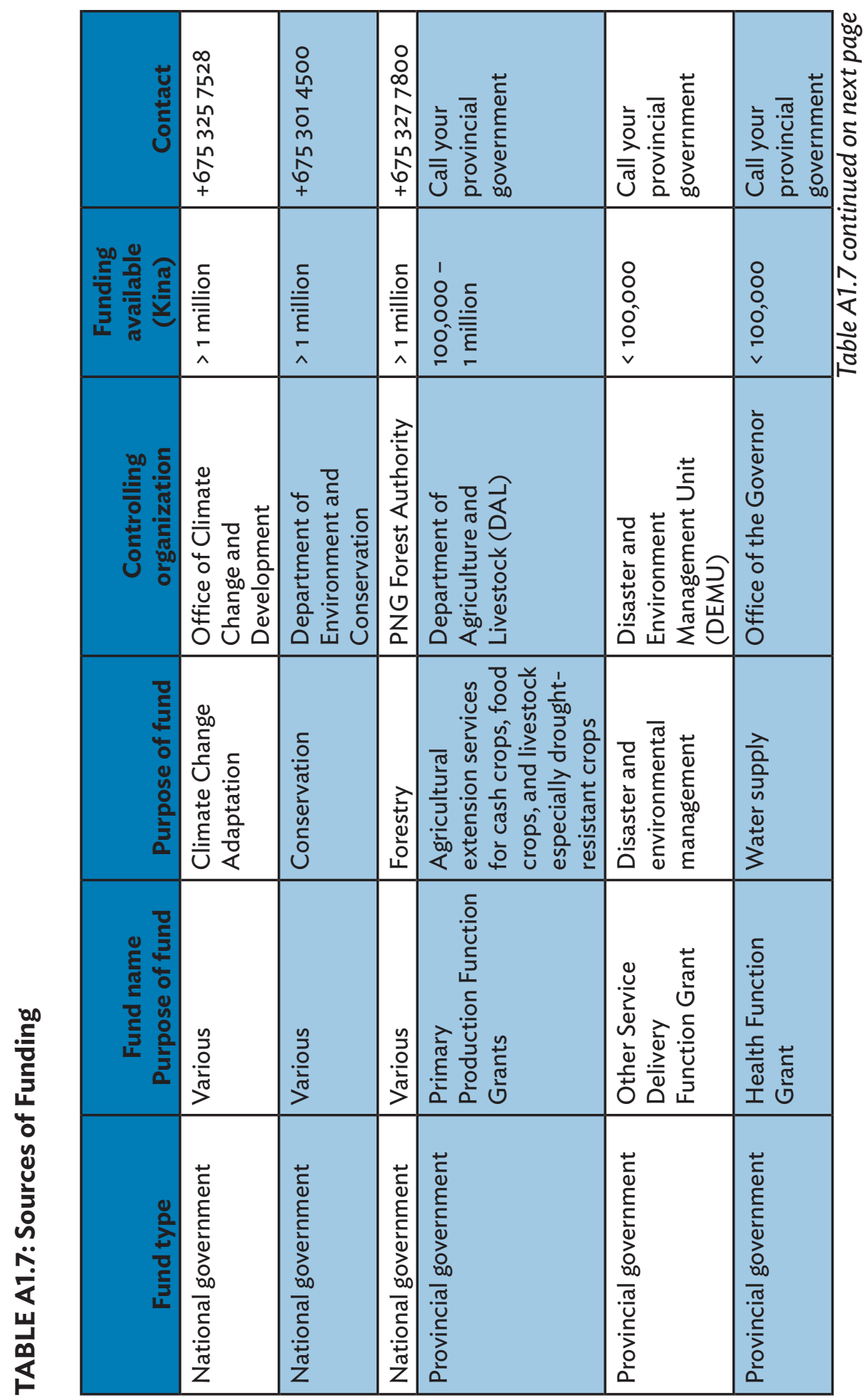




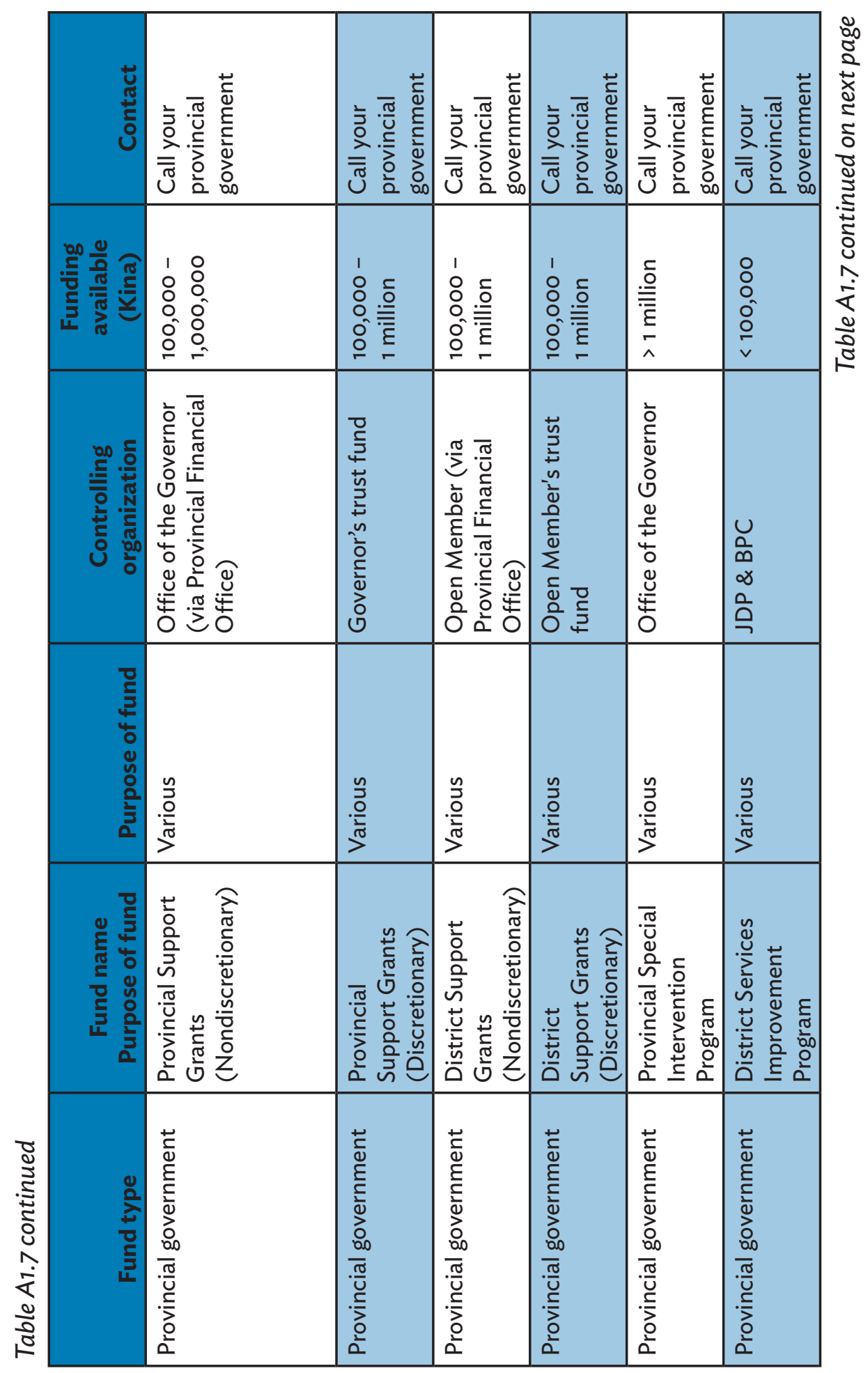




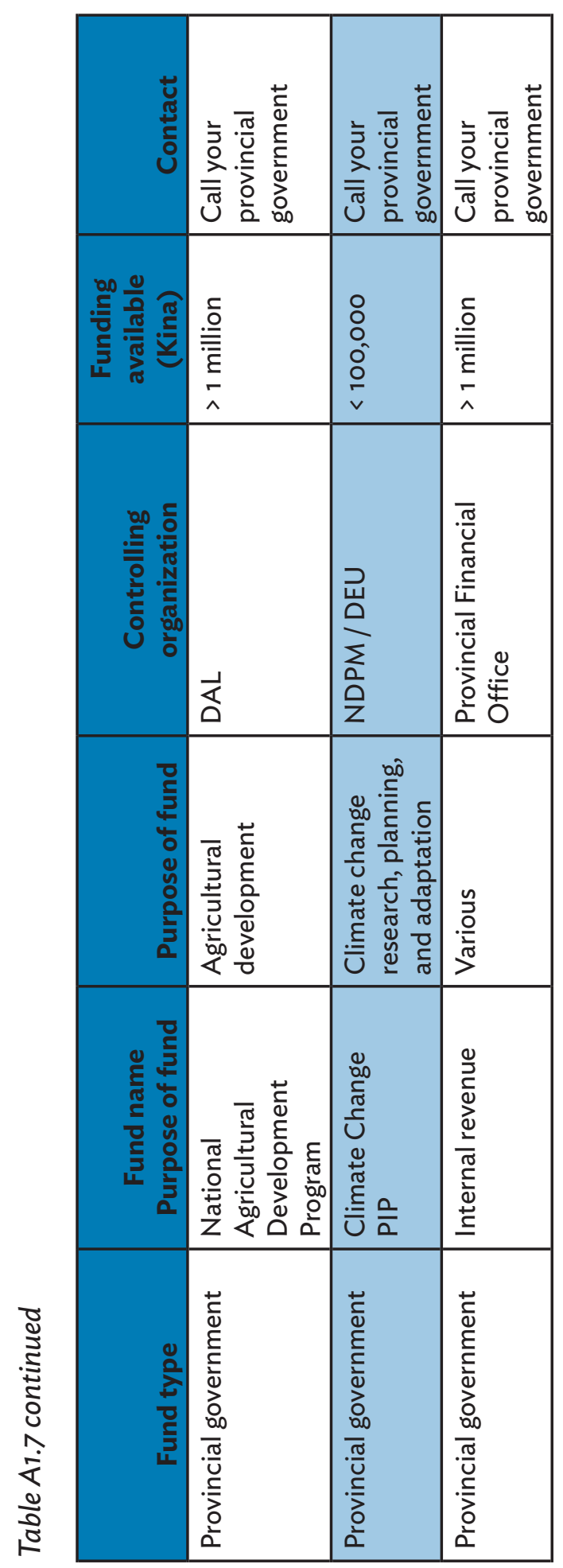


TEMPLATE 2: Forms for Regular Monitoring and Evaluation

\begin{tabular}{|l|l|}
\hline REHABILITATION & \\
\hline Conducted by & $:$ \\
Date Implemented & $:$ \\
Location & $:$ \\
Area & $:$ \\
Layout of Rehabilitation Site & (Pls attach) \\
Condition and Status of Planting Site & $:$ \\
Flooding level & $:$ mn... cm Max... cm \\
& (for Mangrove planting site) \\
\hline Previous land use (if any) & $:$ \\
\hline
\end{tabular}

\section{Details for Planting}

Activities

\begin{tabular}{|c|c|c|c|c|}
\hline Planting & $\begin{array}{l}\text { Number of } \\
\text { Seedling }\end{array}$ & $\begin{array}{l}\text { Date of } \\
\text { Planting }\end{array}$ & Planting & Comment \\
\hline \multicolumn{5}{|l|}{ Planting Stage 1} \\
\hline \multicolumn{5}{|l|}{ Planting Stage 2} \\
\hline \multicolumn{5}{|l|}{ Planting Stage 3} \\
\hline \multicolumn{5}{|c|}{ Replenishment Planting } \\
\hline \multicolumn{5}{|l|}{$\begin{array}{l}\text { Replenishment } \\
\text { Planting Stage } 1\end{array}$} \\
\hline \multicolumn{5}{|l|}{$\begin{array}{l}\text { Replenishment } \\
\text { Planting Stage } 2\end{array}$} \\
\hline \multicolumn{5}{|l|}{$\begin{array}{l}\text { Replenishment } \\
\text { Planting Stage } 3\end{array}$} \\
\hline \multicolumn{5}{|c|}{ * provide information in detail based on species } \\
\hline \multicolumn{5}{|l|}{ Spacing line $(\mathrm{m})$} \\
\hline
\end{tabular}




\section{MONITORING AND EVALUATION RESULTS}

1. Survival rate of plants (\%)

Count result:

\begin{tabular}{|c|l|l|l|l|l|l|}
\hline No. & Species & N Total & $\begin{array}{c}\text { N } \\
\text { Survived }\end{array}$ & N Dead & \% SR & Comments \\
\hline 1 & & & & & & \\
\hline 2 & & & & & & \\
\hline 3 & & & & & & \\
\hline 4 & & & & & & \\
\hline 5 & & & & & & \\
\hline 6 & & & & & & \\
\hline 7 & & & & & & \\
\hline
\end{tabular}

Notes:

$\mathrm{N}$ Total $=$ Total number of seedlings planted at start of project N Survived = Number of seedlings surviving/alive at time of sampling

$\mathrm{N}$ Dead = Number of seedlings surviving/alive at time of sampling $\% \mathrm{SR}=$ Survival rate in percentage

- How to calculate survival rate (SR): $\% S R=$ N Survived $/ N$ Total $\times 100 \%$

I.e. number of seedlings surviving divided by total number of seedlings initially planted and multiplied by $100 \%$.

2. Seedling growth

\begin{tabular}{|c|l|l|l|}
\hline No. & Species & Height (average) & Number of leaves \\
\hline 1 & & & \\
\hline 2 & & & \\
\hline 3 & & & \\
\hline 4 & & & \\
\hline 5 & & & \\
\hline 6 & & & \\
\hline 7 & & & \\
\hline
\end{tabular}


3. Pests and Disease

\begin{tabular}{|l|l|l|l|l|}
\hline \multicolumn{1}{|c|}{ Causing } & Part of Plant & & $\begin{array}{c}\text { \% of Population } \\
\text { Attacked }\end{array}$ & Comment \\
\hline a. Pest & & & & \\
\hline 1 & & & & \\
\hline 2 & & & & \\
\hline 3 & & & & \\
\hline 4 & & & & \\
\hline b. Disease & & & & \\
\hline 1 & & & & \\
\hline 2 & & & & \\
\hline 3 & & & & \\
\hline 4 & & & & \\
\hline
\end{tabular}


APPENDIX 2 


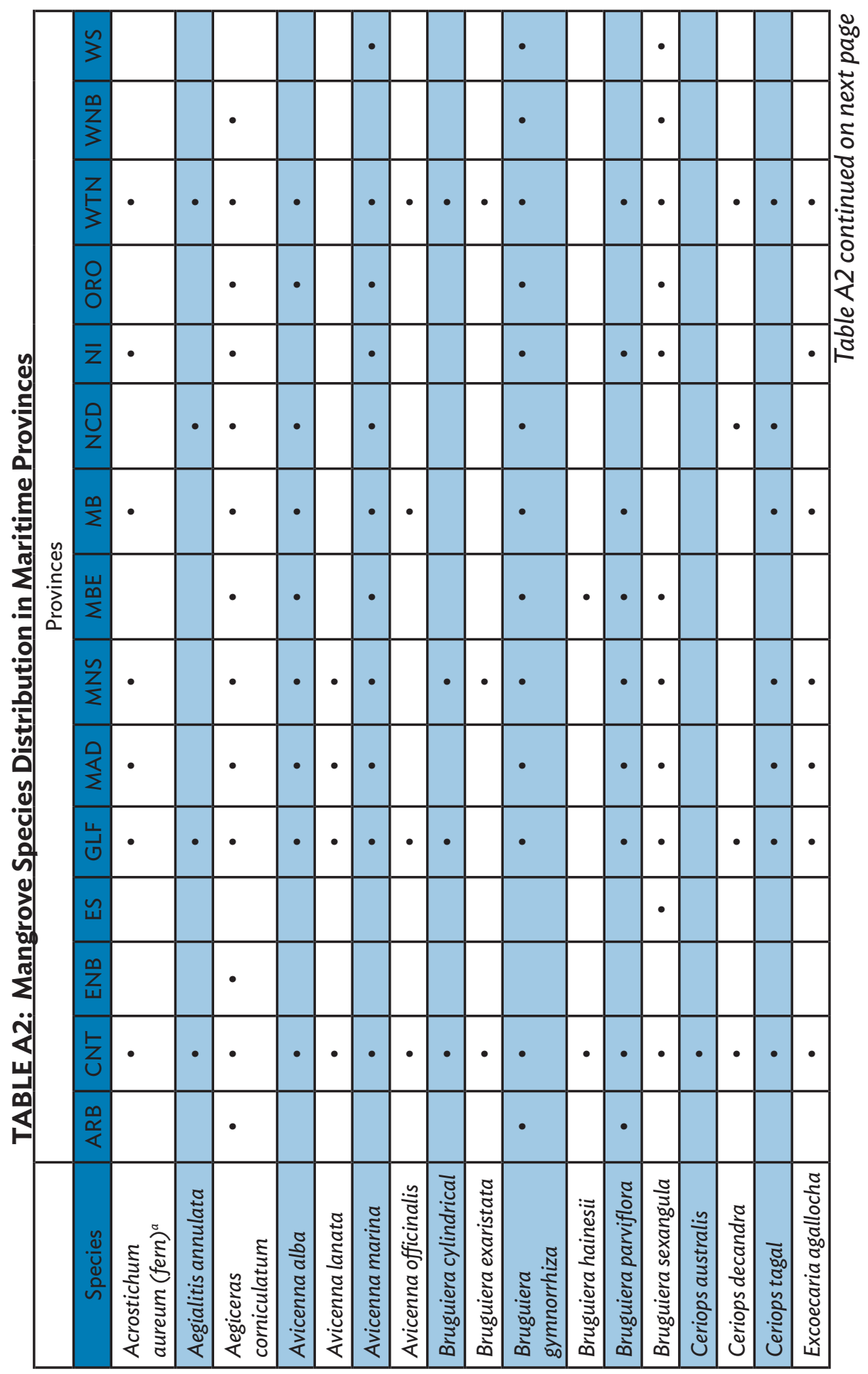




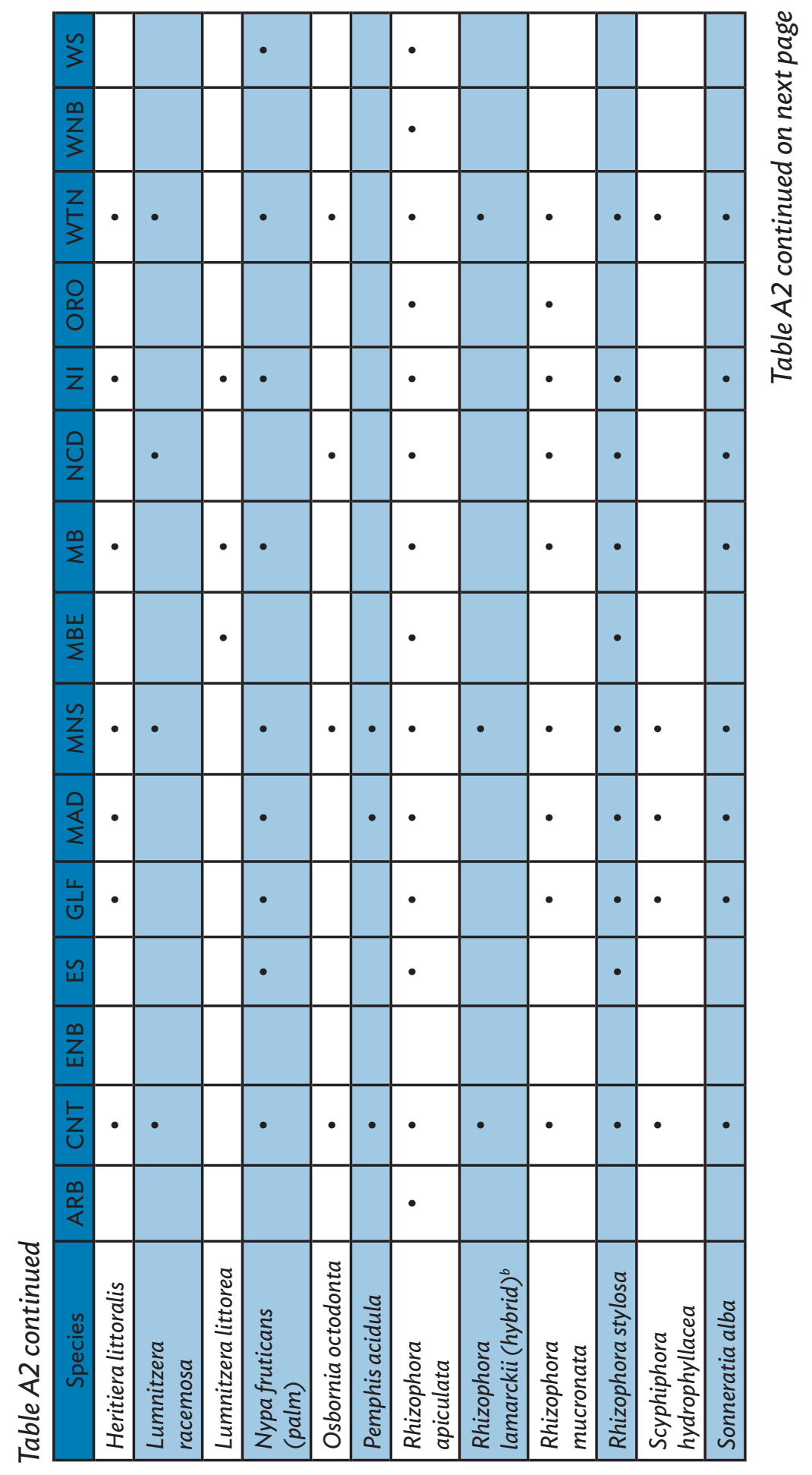




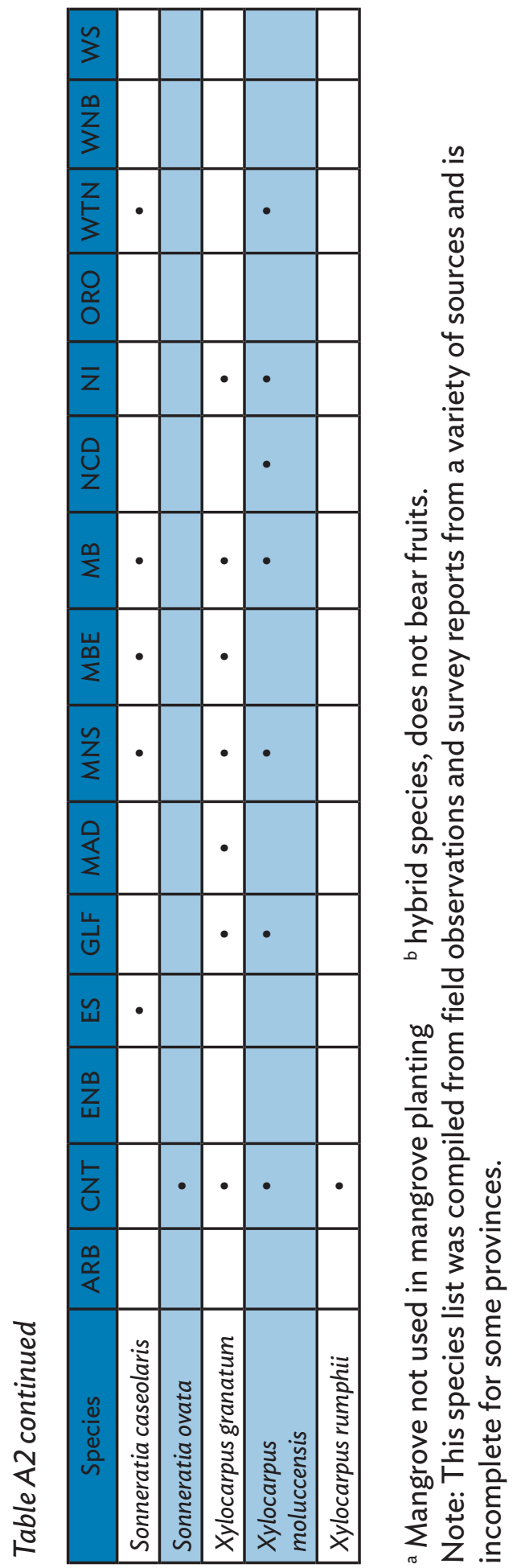




\section{A Community-Based Mangrove Planting Handbook for Papua New Guinea}

This publication is an initiative of the Government of Papua New Guinea that provides step-by-step guidance on how to rehabilitate mangroves. It aims to help address the impacts of climate change, particularly the coastal flooding prevalent in Papua New Guinea. It is a resource for the planting of mangroves for diverse purposes, including carbon absorption, nature conservation, support for fisheries, and ecotourism.

\section{About the Asian Development Bank}

ADB is committed to achieving a prosperous, inclusive, resilient, and sustainable Asia and the Pacific, while sustaining its efforts to eradicate extreme poverty. Established in 1966, it is owned by 67 members -48 from the region. Its main instruments for helping its developing member countries are policy dialogue, loans, equity investments, guarantees, grants, and technical assistance.
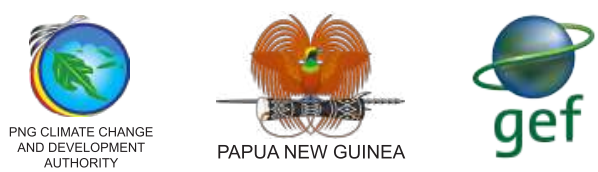

\section{ASIAN DEVELOPMENT BANK}

6 ADB Avenue, Mandaluyong City 1550 Metro Manila, Philippines www.adb.org 